\title{
Road Network Upgrading and Overland Trade Expansion in Sub-Saharan Africa
}

\author{
Piet Buys* \\ Uwe Deichmann \\ David Wheeler
}

\section{Development Research Group World Bank}

\begin{abstract}
World Bank Policy Research Working Paper 4097, December 2006
The Policy Research Working Paper Series disseminates the findings of work in progress to encourage the exchange of ideas about development issues. An objective of the series is to get the findings out quickly, even if the presentations are less than fully polished. The papers carry the names of the authors and should be cited accordingly. The findings, interpretations, and conclusions expressed in this paper are entirely those of the authors. They do not necessarily represent the view of the World Bank, its Executive Directors, or the countries they represent. Policy Research Working Papers are available online at http://econ.worldbank.org.
\end{abstract}

* Authors' names in alphabetical order. Our thanks to the following colleagues for valuable comments and suggestions: Alan Winters (DECRG), Zmarak Shalizi (DECRG), Benno Ndulu (AFRVP), Sanjivi Rajasingham (AFTTR), Anil Bhandari (AFTTR), Lawrence Hinkle (AFTPM), Elke Kreuzwieser (AFTPM), Vivien Foster (AFTPI), Cecilia Briceno-Garmendia (AFTPI), and Jan Hoffmann (UNCTAD). 


\begin{abstract}
Recent research suggests that isolation from regional and international markets has contributed significantly to poverty in many Sub-Saharan African countries. Numerous empirical studies identify poor transport infrastructure and border restrictions as significant deterrents to trade expansion. In response, the African Development Bank has proposed an integrated network of functional roads for the subcontinent. Drawing on new econometric results, this paper quantifies the trade-expansion potential and costs of such a network. We use spatial network analysis techniques to identify a network of primary roads connecting all Sub-Saharan capitals and other cities with populations over 500,000 . We estimate current overland trade flows in the network, using econometrically-estimated gravity model parameters, road transport quality indicators, actual road distances, and estimates of economic scale for cities in the network. Then we simulate the effect of feasible continental upgrading by setting network transport quality at a level that is functional, but less highly-developed than existing roads in countries like South Africa and Botswana. We assess the costs of upgrading with econometric evidence from a large World Bank database of road project costs in Africa. Using a standard approach to forecast error estimation, we derive a range of potential benefits and costs. Our baseline results indicate that continental network upgrading would expand overland trade by about $\$ 250$ billion over 15 years, with major direct and indirect benefits for the rural poor. Financing the program would require about \$20 billion for initial upgrading and $\$ 1$ billion annually for maintenance. We conclude with a discussion of supporting institutional arrangements and the potential cost of implementing them.
\end{abstract}




\section{Introduction}

This paper presents evidence on the trade-expansion potential of improvements in Sub-Saharan Africa's road network. The impetus for our work is well-summarized by the following description of a trucker's journey in Cameroon:

"The plan was to carry 1,600 crates of Guinness and other drinks from the factory in Douala where they were brewed to Bertoua, a small town in Cameroon's south-eastern rainforest. According to a rather optimistic schedule, it should have taken 20 hours, including an overnight rest. It took four days. When the truck arrived, it was carrying only two-thirds of its original load....we were stopped at road-blocks 47 times. ... Our road was rendered impassable by rain three times, causing delays of up to four hours. The Cameroonian government has tried to grapple with the problem of rain eroding roads by erecting a series of barriers ... that stop heavy trucks from passing while it is pouring. ... Early on the second evening ... we met a [locked] rain barrier in the middle of the forest. It was dark, and the man with the key was not there. ,,, he returned shortly before midnight. The hold-up was irritating, but in the end made no difference. Early the next morning, a driver coming in the opposite direction told us that the bridge ahead had collapsed, so we had to turn back. (The Economist (2002)) ${ }^{1}$

In this case, the driver did not even face a long wait at a border station. According to the African Development Bank (ADB, 2003), roadblocks and border controls add four to seven days to the three-day trip from Bangui, Central African Republic, to Douala, Cameroon. The ADB also estimates that a loaded truck on the Bangui-Douala road pays about $\$ 580$ at local barricades en route. A recent study by the Economic Community of West African States found up to seven check points per $100 \mathrm{~km}$ on parts of the region's road network.

Similar conditions prevail in much of the subcontinent, and overland transport is so difficult and costly that Africa's diverse regions remain largely isolated from one another. Overland trade between the large urban centers of West Africa and South Africa is basically nonexistent. Within many countries, abundant fertile soil lies fallow because

\footnotetext{
${ }^{1}$ According to one critique of this story, some roads traveled were particularly bad because the trucker avoided parts of the main road where roadblock costs were even higher. In any case, the critique reinforces the main point. Our thanks to our colleague Elke Kreuzwieser for drawing our attention to this.
} 
hauling produce to market is too expensive, time-consuming and dangerous for truckers. Numerous empirical studies have examined the economic impact of poor roads. ${ }^{2}$ Amjadi $\&$ Yeats (1995) find that the relatively low level of Sub-Saharan African exports is essentially due to high transport costs. In a study of transport costs and trade, Limao \& Venables (2000) find that poor infrastructure accounts for $60 \%$ of transport costs for landlocked countries, as opposed to $40 \%$ for coastal countries.

Simuyemba (2000) has responded to this problem by calling for a more integrated approach to infrastructure planning in Africa:

... Africa needs a deliberate, systematic and concerted effort at the practical level to integrate, upgrade and modernize regional infrastructure so that it becomes the catalyst for Africa's growth. The regionally integrated corridor approach offers prospects for speedier integration of infrastructure systems in Africa. The vision and ultimate objective for Africa should be to create a single market of 750 million people that is competitive within itself and within the global economy. A critical pre-requisite to this is regional infrastructure integration across Africa.

The World Bank and the African Development Bank (ADB) have both launched initiatives to encourage more integrated infrastructure development. The Bank's SubSaharan Africa Transport Policy Program (SSATP) has focused on regional and national programs for transport development (World Bank, 2003). The ADB has proposed development of a transcontinental road network, with seven major road corridors in SubSaharan Africa (ADB, 2003). Figure 1 depicts the ADB's proposed road network.

How much difference would an integrated, functional road network make for African development? This paper extends the previously-cited work by quantifying the economics of continental road network upgrading. Specifically, we use econometric

${ }^{2}$ See Henderson, Shalizi \& Venables (2001) for a review of the literature. 
evidence and spatial network analysis techniques to explore the relationship between road transport quality and overland trade in Sub-Saharan Africa.

Figure 1: The ADB’s Proposed Highway Corridors (in bold) in Sub-Saharan Africa

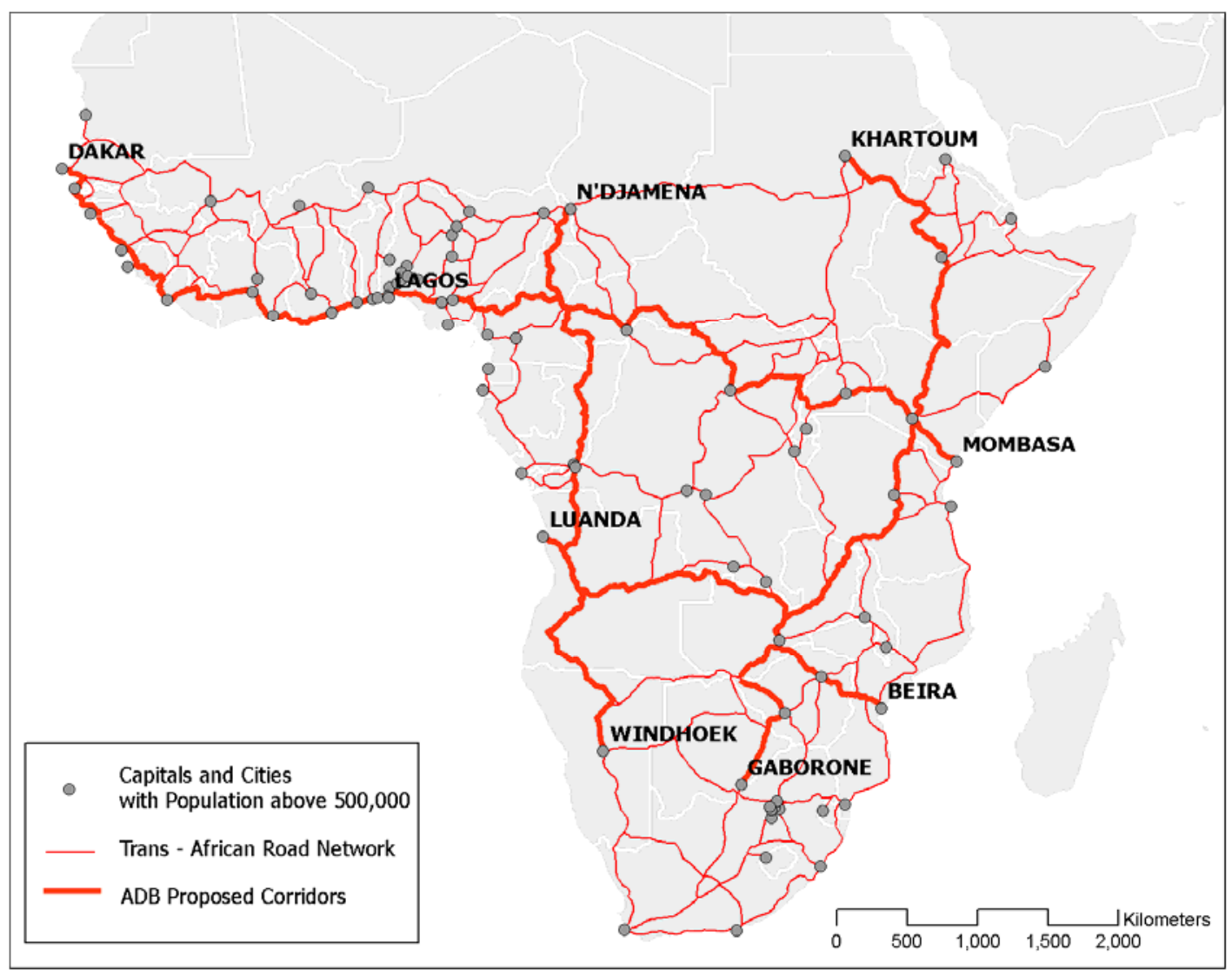

We employ the conventional gravity model, which has provided a robust fit to the data in many recent studies of trade flows between cities, countries and regions. In this model, the volume of trade between two areas is directly proportional to their economic activity levels, and inversely proportional to the cost of transporting goods between them. In Africa, the cost of overland transport is greatly magnified by bad roads, difficult border crossings, and harassment of truckers at road blocks. Our modeling exercise estimates the trade growth that would result from removal of these difficulties, as well as the associated costs. 
The remainder of the paper is organized as follows. Section 2 reviews the theoretical and empirical literature on gravity models, highlighting evidence on overland trade flows in developing countries. In Section 3, we use computer mapping to identify a network of primary roads connecting all 42 mainland Sub-Saharan capitals, along with 41 other cities with populations over $500,000 .^{3}$ Section 4 estimates a gravity model for SubSaharan Africa, using inter-country trade data, road transport quality indicators, actual road distances, and estimates of economic scale for trading partners. We use the results to estimate current trade flows in the inter-city network, and to simulate the impact of a major improvement in road network quality. We explore the implications of our results for trade expansion at the regional, country and city levels. In Section 5 we estimate the costs of network improvement, using a World Bank database of upgrading and maintenance costs for hundreds of African road projects. Section 6 considers the environmental implications of network upgrading, and suggests ways in which new data on African biodiversity could be integrated into network planning. Drawing on our empirical results, Section 7 considers the establishment of a consortium to finance, administer and maintain the network. The consortium would join participating states and donor institutions in a long-term collaboration for road improvement, relaxation of trade restrictions, and overland trade expansion in Sub-Saharan Africa. Section 7 also estimates the cost of operating the network-wide consortium for 15 years. Section 8 concludes the paper by summarizing our benefit and cost estimates, as well as offering some thoughts on the feasibility of continental-scale upgrading.

\footnotetext{
${ }^{3}$ Our analysis excludes Madagascar, Sao Tome and Principe, the Comoros, and other island states that are considered part of Sub-Saharan African.
} 


\section{Gravity Models of Trade}

Empirical studies of transportation costs and trade often rely on the traditional gravity model, which relates the volume of trade between cities, countries or regions to their economic scales and the distance between them. In addition, some developingcountry studies adjust for the quality of road transport infrastructure:

(1) $T_{i j}=k\left(X_{i j}\right) \frac{E_{i}^{\alpha_{i}} M_{j}^{\alpha_{j}} q_{i j}^{B}}{d_{i j}^{\gamma}}$

where $\mathrm{T}_{\mathrm{ij}}=$ Trade volume between areas $\mathrm{i}$ and $\mathrm{j}$.

$\mathrm{E}_{\mathrm{i}}=$ Economic scale of the exporting area

$\mathrm{M}_{\mathrm{j}}=$ Economic scale of the importing area

$\mathrm{q}_{\mathrm{ij}}=$ Quality of road transport between areas $\mathrm{i}$ and $\mathrm{j}$

$\mathrm{d}_{\mathrm{ij}}=$ Road distance between areas $\mathrm{i}$ and $\mathrm{j}$

$\mathrm{X}_{\mathrm{ij}}=\mathrm{A}$ vector of other trade-cost-related variables.

Distance proxies travel cost in developed-country gravity models, because road quality is assumed to be uniformly high. In developing countries, where road conditions vary greatly, the element $\left[\mathrm{d}^{\gamma} / \mathrm{q}^{\beta}\right]$ provides a closer approximation to the cost factor. The adjustment factor $\mathrm{k}$, a constant multiplier in the core gravity model, can also be related to a vector of other relevant variables, $X_{\mathrm{ij}}$, such as indicators of linguistic, political and economic ties between trading partners.

Empirical studies of the core gravity model, originated by Tinbergen (1962) and Pöyhönen (1963), have since been rationalized from several theoretical perspectives. Anderson (1979), Helpman and Krugman (1985), Bergstrand (1985, 1989, 1990), and Rossi-Hansberg (2005) have all derived equation (1) from models of trade that include imperfect competition and/or increasing returns to scale. Deardorff (1998) has derived the same equation from two Heckscher-Ohlin cases: frictionless trade and trade in 
heterogeneous goods. ${ }^{4}$ Recent empirical studies have fitted a variety of augmented gravity models to international trade data. Frankel (1997) tests for the effects of a common border, per capita GDP, a common language, and membership in regional trading arrangements, as well as economic scale and distance. Rose (2000) augments Frankel's model by introducing colonial ties, exchange rate volatility and a common currency. Soloaga and Winters (2001) provide a further control for effective distance, by introducing a measure of generalized remoteness from all potential trade partners. Carillo and Li (2002) include the effects of a common border and trade association membership in a gravity-model analysis of Latin American trade. In an econometric analysis of trade links among seven of eight West African Economic and Monetary Union (WAEMU) countries ${ }^{5}$ and other states, Coulibaly and Fontagné (2004) augment distance with measures of transport infrastructure quality: percent of roads that are paved and quality of border-station customs services. ${ }^{6}$

Most of the cited econometric studies employ a log-transformation of the gravity model:

(2) $\log T_{i j}=k_{0}+\alpha_{i} \log E_{i}+\alpha_{i} \log M_{j}+\beta \log q_{i j}+\gamma \log d_{i j}+\varepsilon_{i j}$

Estimation techniques vary with the cross-sectional and time series properties of the data. The econometric results of Carillo and Li for Latin America and Coulibaly and Fontagné for West Africa are of particular interest for this paper, because both focus on developing regions. In addition, Coulibaly and Fontagné control for West African road infrastructure

\footnotetext{
${ }^{4}$ For summaries of the relevant literature, see Yamarik and Ghosh (2005) and Feenstra, Markusen and Rose (2001).

5 The WAEMU countries are Togo, Benin, Cote d'Ivoire, Guinea Bissau, Senegal, Mali, Burkina Faso and Niger. Guinea-Bissau was excluded from the Coulibaly- Fontagné study because its foreign trade data were not available.

${ }^{6}$ For other recent empirical work on intra-African trade, see Kirkpatrick and Watanabe (2005), Chauvin and Gaulier (2002), Longo and Sekkat (2004) and Musila (2005).
} 
quality. ${ }^{7}$ Although the two studies fit gravity models to very different data sets, Table 1 shows that their core results are qualitatively similar: Exporter GDP elasticities between 1.0 and 2.0; importer elasticities around 1.0; and road distance elasticities between -1.0 and -1.7. In addition, the Coulibaly / Fontagné results suggest a road quality elasticity near 1.5.

Table 1: Recent Gravity Model Estimates for Africa and Latin America ${ }^{a}$

\begin{tabular}{|l|c|c|c|c|}
\hline Study & Exporter GDP & Importer GDP & $\begin{array}{c}\text { Road } \\
\text { Distance }\end{array}$ & $\begin{array}{c}\text { Road } \\
\text { Quality }\end{array}$ \\
\hline $\begin{array}{l}\text { Coulibaly and Fotagné } \\
\text { (West Africa) }^{\mathrm{b}}\end{array}$ & 1.40 & 0.83 & -.96 & 1.44 \\
\hline Carrillo and Li, & $(22.29)$ & $(6.05)$ & $(4.93)$ & $(4.34)$ \\
(Latin America) $^{\mathrm{c}}$ & $1.33-2.13$ & $0.69-1.23$ & $-1.13--1.68$ & \\
\hline
\end{tabular}

a t-statistics in parentheses

b Coulibaly and Fotagné (2004), Table 5, Column 6, p. 29

${ }^{c}$ Carrillo and Li (2002), Table 5, Columns 1-5, p. 27

\section{Mapping the Trans-African Road Network}

To assess the potential for overland trade expansion, we analyze a road system that includes the Trans African Highway corridors proposed by the African Development Bank (ADB, 2003). ${ }^{8}$ Using a computerized map and spatial network analysis software, we configure a distance-minimizing network of existing primary roads that connects all mainland capitals and cities above 500,000 population. ${ }^{9}$ Figure 2 displays the network, along with the 83 connected cities. ${ }^{10}$ Since the network covers all major cities, it has more connections in countries with large populations. Nigeria has 18 cities in the

\footnotetext{
${ }^{7}$ Coulibaly and Fontagné use two-stage least squares to allow for the potential endogeneity of road quality. Their model is fitted to the UN Statistics Division's COMTRADE data for the period 1996-1998.

${ }^{8}$ The ADB's corridors include North African countries, while our analysis is limited to Sub-Saharan Africa.

9 African roads are functionally categorized as primary, secondary or tertiary, depending upon whether they connect principal centers, secondary centers, or peripheral areas. Road conditions vary widely by country, so functional categories convey little information about road quality. Primary roads in South Africa are paved, all-weather highways, while many primary roads in the Congo D.R. are unpaved.

${ }^{10}$ Appendix Table A1 lists all cities in the network.
} 
network, South Africa has 9, and the Democratic Republic of Congo has 6. The complete network contains 885 road segments, joining 3,403 paired combinations of cities. Our index of country road quality is determined by the following equation:

(3) $Q_{j}=P_{j}^{\alpha_{1}} G_{j}^{\alpha_{2}} C_{j}^{\alpha_{3}}$

where

$\mathrm{Q}_{\mathrm{j}}=$ Road quality index for country $\mathrm{j}$

$P_{j}=$ Percent of roads that are paved in country $j$

$\mathrm{G}_{\mathrm{j}}=$ GDP per capita in country $\mathrm{j}$ (an index of capacity to maintain roads)

$\mathrm{C}_{\mathrm{j}}=$ The World Bank's Country Policy and Institutional Capacity (CPIA) index for transparency, accountability and corruption in country $\mathrm{j}$ (a proxy for delays and costs inflicted on truckers). ${ }^{11}$

Figure 2: Trans-African Network, Based on Existing Primary Roads

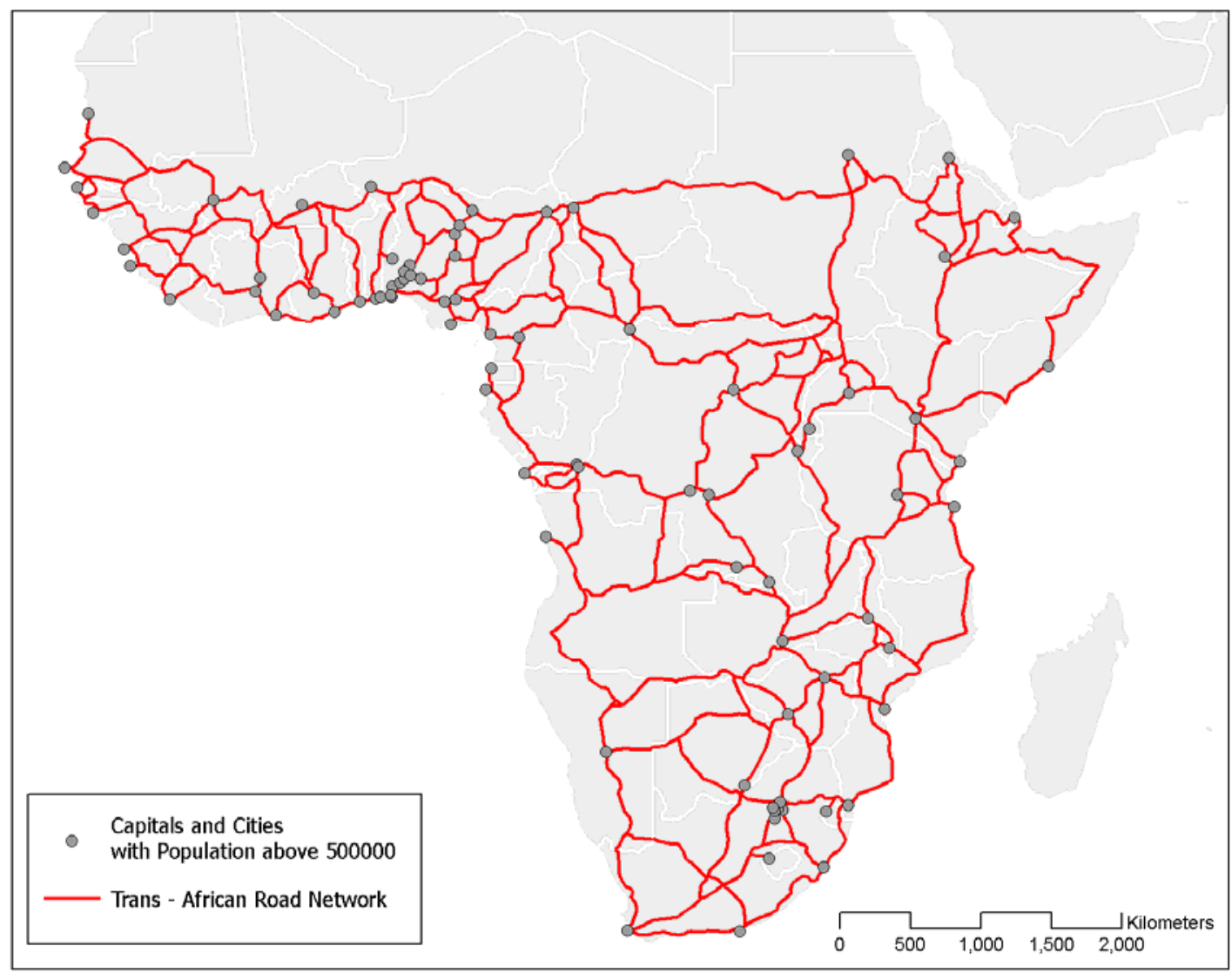

11 Data definitions are as follows:

$\mathrm{P}_{\mathrm{j}}$ : Paved roads (\% of total roads), 1999 (World Bank, World Development Indicators 2004)

$\mathrm{G}_{\mathrm{j}}$ : GDP per capita 2001, PPP (constant 2000 international \$) (World Development Indicators 2004)

$\mathrm{C}_{\mathrm{j}}$ : From the World Bank's CPIA database, 2004 
We believe that a mildly increasing-returns function $\left(\alpha_{1}=0.8 ; \alpha_{2}=0.2 ; \alpha_{3}=0.2\right)$

provides a reasonable approximation to road transport quality differentials in Sub-

Saharan Africa. ${ }^{12,13}$ Table 2 presents index values by country, normalized to 100 for the

highest-quality road transport (in South Africa). Estimated road quality for Botswana

(87.5) is over 20 times the quality for the Democratic Republic of the Congo (3.8). We

believe that this does not overstate the existing differential in average road speed, vehicle

depreciation on bad roads, harassment of truckers, payments at road blocks, and frontier

difficulties. $^{14}$

\section{Simulating Trade Flows in the Network}

Our objective is to develop a gravity model for inter-city trade that can be used for

analysis of road improvement impacts at the country, regional and continental levels. We

begin by estimating a gravity model for Sub-Saharan Africa, using recent inter-country

\footnotetext{
${ }^{12}$ The authors' extensive experience with African roads suggests that "percent paved" alone is an inadequate proxy for road quality. Many stretches of "paved" road in Sub-Saharan Africa are in extremely poor condition, either because government revenues are insufficient to support proper maintenance, or corrupt officials have diverted the maintenance funds. We use per capita income and the CPIA corruption index to incorporate these factors, although we stay relatively close to the Coulibaly-Fontagné index by giving percent paved twice the combined weight of the other two factors in our road quality measure. We have made one adjustment to the published paved-road data, which assign South Africa a paved road percentage of 19.7 (in contrast to Botswana, with 54\% and Zimbabwe, with 47.4\%). We believe that this grossly misrepresents the relevant road conditions in South Africa, since its components of our primary network are all paved, first-class roads. To ensure a measure that is higher than those for Botswana and Zimbabwe, we have arbitrarily assigned South Africa a paved road percent of 60 for our index. This probably underestimates relative South African road quality. However, it has no effect on our results because we assume that South Africa's roads (with a continental-maximum index score of 100) do not need improvement in the upgraded network.

13 We have tested our road quality index against current road quality data gathered by the ADB in its assessment of seven potential road corridors in 31 Sub-Saharan African countries. This is a partial view, because the ADB assessment focuses on physical road quality while our index also attempts to incorporate costs and delays at frontiers and internal road barricades. Nevertheless, we find a robust statistical relationship ( $\rho=-0.57,99 \%$ significance) between our road quality index and the percent of the road network rated poor by the ADB.

${ }^{14}$ Arbitrary rescaling of the road quality index in the log-log regression equation (2) does not affect the underlying marginal relationship between $\log$ (trade) and $\log$ (original road quality index). For example, substituting the square of the original road quality index (which doubles the original log value) will simply halve the regression coefficient. Using the square root of the index (which halves the original log value) will double the regression coefficient.
} 
trade data, road transport quality indicators, actual road distances, and estimates of economic scale for trading partners.

Table 2: Road Transport Quality Indices for Sub-Saharan Countries

\begin{tabular}{|l|c|l|l|c|}
\hline Country & $\begin{array}{c}\text { Road Transport } \\
\text { Quality Index }\end{array}$ & Country & $\begin{array}{c}\text { Road } \\
\text { Transport } \\
\text { Quality Index }\end{array}$ \\
\hline South Africa & 100.0 & & Cameroon & 18.4 \\
\hline Botswana & 87.5 & & Mauritania & 16.6 \\
\hline Zimbabwe & 50.0 & & Mali & 16.5 \\
\hline The Gambia & 41.6 & & Kenya & 16.3 \\
\hline Sudan & 40.4 & & Angola & 15.8 \\
\hline Togo & 37.0 & & Ethiopia & 15.1 \\
\hline Senegal & 36.0 & & Cote d'Ivoire & 14.4 \\
\hline Nigeria & 32.3 & & Congo & 13.6 \\
\hline Swaziland & 27.4 & & Guinea-Bissau & 13.2 \\
\hline Ghana & 27.0 & & Somalia & 12.4 \\
\hline Namibia & 25.9 & & Rwanda & 12.4 \\
\hline Lesotho & 25.7 & & Niger & 11.0 \\
\hline Zambia & 25.1 & & Burundi & 10.9 \\
\hline Benin & 25.1 & & Uganda & 10.7 \\
\hline Eritrea & 25.0 & & Sierra Leone & 9.6 \\
\hline Guinea & 23.1 & & Liberia & 7.1 \\
\hline Mozambique & 23.1 & & Equatorial Guinea & 6.5 \\
\hline Burkina Faso & 21.2 & & Tanzania & 6.2 \\
\hline Malawi & 20.4 & & Central African Republic & 4.4 \\
\hline Gabon & 19.2 & & Dem. Rep. of Congo & 3.8 \\
\hline Djibouti & 18.5 & & Chad & 1.8 \\
\hline
\end{tabular}

\subsection{Gravity Model Estimation: Data}

We estimate a standard gravity model for inter-country trade in Sub-Saharan Africa using the IMF Direction of Trade (IMFDOT) data. ${ }^{15}$ For paired trading partners, we calculate average trade flows for the period 2000-03. ${ }^{16}$ Our economic scale variables for each trading pair are average exporter and importer GDP's at purchasing power parity for

\footnotetext{
${ }^{15}$ The IMF direction of trade database includes total merchandise trade exports and total imports by partner, reported yearly, quarterly and monthly. This database provides more complete information on African trade flows than the UN COMTRADE data.

${ }^{16}$ We estimate average flows to compensate for the frequency of missing values in the annual data series. We use the period 2000-03 to match the trade data with available data for the right hand variables in the model.
} 
2000-03. The distance index is average road distance for all city pairs in the country trading pair (e.g., Senegal/South Africa road distance is indexed by the average distance for Dakar/Johannesburg, Dakar/Cape Town, and all other relevant city pairs). Similarly, our road quality index is the average index for all city pairs in the trading country pair. We also test for the effect of six regional trading agreements, whose member countries are listed in Appendix Table A7.

We have two basic options for indexing the quality of the road links between pairs of cities: the distance-weighted average road quality index for transit countries, or the minimum quality index for those countries. We believe that the latter index is more appropriate. Consider, for example, the problem of a business manager in Johannesburg who is considering overland shipment to a customer in Lagos. As Table 3 shows, the minimum distance route passes through nine countries, whose road qualities vary from 100 (South Africa) to 3.8 (D.R. of Congo).

Using the distance-weighted average road quality (30.1), the shipper would view the trip as equivalent to a $7,515-\mathrm{km}$ journey at the $82^{\text {nd }}$ percentile of Sub-Saharan road quality (see Table 2). However, the trip would involve passage through the Democratic Republic of Congo, with some of the worst road conditions on the continent, as well as extensive travel in several other countries with poor conditions (e.g., Angola, Congo Republic). We believe that even moderately risk-averse managers would choose ocean or air shipment from Nigeria to South Africa rather than risk the trip through Central Africa, and the available evidence is consistent with this view. 
Table 3: Overland Trip, Johannesburg - Lagos (Network Minimum Distance Route)

\begin{tabular}{|l|r|r|}
\hline Country & $\begin{array}{c}\text { Distance } \\
(\mathrm{km})\end{array}$ & $\begin{array}{c}\text { Road } \\
\text { Quality }\end{array}$ \\
\hline South Africa & 313.6 & 100.0 \\
\hline Botswana & 842.0 & 87.5 \\
\hline Namibia & 1056.2 & 25.9 \\
\hline Angola & 1875.8 & 15.8 \\
\hline Congo DR & 582.3 & 3.8 \\
\hline Congo Rep. & 389.7 & 13.6 \\
\hline Gabon & 820.0 & 19.2 \\
\hline Cameroon & 829.8 & 18.4 \\
\hline Nigeria & 805.3 & 32.3 \\
\hline Total & 7514.7 & 30.1 \\
\hline
\end{tabular}

Even though South Africa and Nigeria have the two largest economies in SubSaharan Africa, overland shipments between them seem almost nonexistent. ${ }^{17}$ For this reason, we believe that minimum road link quality (for D.R. of Congo, in this case), provides a better index than average link quality. However, we also report econometric results for average link quality.

Table 4 provides suggestive evidence on the effect of bad roads on overland transport. Using 2004 IMFDOT data, we calculate total import and export flows between Chad and Central African Republic, two landlocked north-central African states, and two sets of countries: their neighboring states (each other, as well as Niger, Nigeria, Cameroon, Congo, Democratic Republic of Congo and Sudan), and five central-southern African landlocked (CSAL) states: Rwanda, Burundi, Malawi, Zambia and Zimbabwe. These states are separated from Chad and Central African Republic by only one country: Democratic Republic of Congo, which has extremely low road quality. For contrast, we also present total trade flows for the CSAL countries in Table 4. Together, trade flows

\footnotetext{
${ }^{17}$ After an extensive search, we can find no evidence of regular overland trade between Nigeria (or, for that matter, West Africa) and South Africa.
} 
between Chad and CAR and their neighboring states are $\$ 103.7$ million for imports and $\$ 10.1$ million for exports. Trade flows with the CSAL states, only one country removed, are effectively nonexistent. By contrast, the CSAL states' total trade flows with other African states are $\$ 3.3$ billion for imports and $\$ 1.6$ billion for exports.

Table 4: Trade Flows Linking Chad and CAR with Neighboring and CSAL States (\$US 2004)

\begin{tabular}{|c|r|r|}
\hline Chad and CAR & Imports & \multicolumn{1}{l|}{ Exports: } \\
\hline Neighboring African States & $103,692,188$ & $10,079,443$ \\
\hline CSAL States & 356 & 0 \\
\hline CSAL States (Total African trade) & $3,252,777,590$ & $1,640,256,173$ \\
\hline
\end{tabular}

\subsection{Gravity Model Estimation: Results}

Table 5 provides estimation results for alternative specifications of the log-log regression model in equation (2). ${ }^{18}$ Columns (1) and (2) present results for the basic gravity model, with two country-level measures of road quality. Road-quality results in both columns are based on average values for city pairs in each pair of trading countries. Column (1) presents results for average link quality between city pairs, while (2) tabulates results for minimum link quality. As we explained above, we believe that the latter is more realistic. In the econometric analysis, the city-level distinction between the two measures is blurred by averaging in our country-level dataset. In any case, both measures yield strong results, with elasticities around 2.0 (a 2\% increase in trade for each $1 \%$ increase in road quality) and very high levels of significance. For both measures, the elasticities are somewhat higher than those obtained by Coulibaly and Fontagné. We

\footnotetext{
${ }^{18}$ The model is estimated using trade flows between countries where each country is both an exporter and importer. The actual number of trading partners included is 36 since trade for the five countries in the South African Customs Union is reported jointly and no trade data are available for Somalia and Liberia. In addition, no trade is reported for 132 country pairs where it is not clear whether this is due to non-reporting or actual absence of trade. The final number of observations is thus 1128 .
} 
present results for minimum link quality in the other columns of Table (5), but average link quality retains a large elasticity and high significance in the same specifications.

We obtain very strong results for exporter GDP, importer GDP and road network distance. The GDP elasticities are both in the upper range for the previous studies summarized in Table 1, and both have very high significance levels. Road distance is also highly significant, with the expected sign and elasticities that are somewhat larger than previous estimates for West Africa and Latin America. ${ }^{19}$

Columns (3) and (4) augment the gravity model with controls for six regional trade agreements that are identified in Table 5 and Appendix Table A7. Three of these agreements - WAEMU (West Africa), CEMAC (Central Africa) and EAC (East Africa) - are among contiguous states with very long-standing monetary and trade relationships. ${ }^{20}$ The other three - ECOWAS, SADC and COMESA - are broader and looser aggregates that overlap somewhat with the first three agreements. ${ }^{21}$ Our results suggest that the close-knit agreements have had a major impact on trade, ceteris paribus. The highly-significant dummy-variable results for WAEMU and CEMAC, in the range 2.3 - 3.4, suggest trade volumes 10-30 times higher than expected volumes without the agreements. The estimated parameter for EAC is equally large, although it is only

\footnotetext{
19 Although we have considered panel estimation, we have chosen cross-section estimation for several reasons. First, as we have previously noted, frequent missing values in the data force us to use a 4-year average, even for the cross-section work. At best, we could estimate a pseudo-panel regression with an equivalent average for a previous period in the 1990's. Even if we adopted this approach, we would confront intractable problems with our road quality index. The cross-country index in Table 2 follows a sensible pattern but, as we have noted, World Development Indicator statistics on percent paved roads exhibit significant short-period fluctuations that seem very unlikely to reflect changes in actual road quality. In any case, we have no time-compatible measures for the CPIA index, which only exists for recent years. The objective of this exercise is to predict the effect of a hypothetical change in road quality which, given the measurement issues, could only enter a pseudo-panel regression as a fixed effect. The same is true for road distance. After considering all of these problems, we have decided against any attempt at panel estimation.

${ }^{20}$ We cannot test the effect of the South African Customs Union (SACU - Botswana, Lesotho, Namibia, South Africa, Swaziland)) because the relevant inter-country observations are missing in the data.

${ }^{21}$ Appendix Table A7 lists member countries of WAEMU, CEMAC, EAC, ECOWAS, COMESA and SADC.
} 
Table 5: Gravity Model Regressions for Sub-Saharan Africa: Paired Trading Countries

Dependent Variable: Log Trade Value (\$US)

\begin{tabular}{|c|c|c|c|c|c|}
\hline & (1) & (2) & (3) & (4) & (5) \\
\hline \multirow[t]{2}{*}{ Log Exporter GDP } & 1.563 & 1.656 & 1.710 & 1.706 & 1.709 \\
\hline & $(12.38)^{\star \star}$ & $(13.54)^{\star \star}$ & $(13.92)^{\star \star}$ & $(13.97)^{\star \star}$ & $(14.04)^{\star \star}$ \\
\hline \multirow[t]{2}{*}{ Log Importer GDP } & 1.295 & 1.386 & 1.434 & 1.433 & 1.435 \\
\hline & $(10.26)^{\star \star}$ & $(11.23)^{\star \star}$ & $(11.62)^{\star \star}$ & $(11.64)^{\star \star}$ & $(11.69)^{\star \star}$ \\
\hline \multirow[t]{2}{*}{ Log Avg. Road Quality } & 1.984 & & & & \\
\hline & $(4.78)^{\star \star}$ & & & & \\
\hline \multirow[t]{2}{*}{ Log Min. Road Quality } & & 1.872 & 2.067 & 1.991 & 1.932 \\
\hline & & $(7.79)^{\star \star}$ & $(7.99)^{\star \star}$ & $(8.07)^{\star \star}$ & $(8.09)^{\star \star}$ \\
\hline \multirow[t]{2}{*}{ Log Road Distance } & -3.836 & -2.531 & -2.308 & -2.048 & -2.096 \\
\hline & $(18.66)^{\star \star}$ & $(9.60)^{\star \star}$ & $(7.46)^{\star \star}$ & $(7.26)^{\star \star}$ & $(7.55)^{\star \star}$ \\
\hline \multirow{2}{*}{$\begin{array}{l}\text { Trade Agreement Member } \\
\text { [WAEMU,CEMAC,EAC] }\end{array}$} & & & & & 2.742 \\
\hline & & & & & $(4.63)^{\star \star}$ \\
\hline \multirow[t]{2}{*}{ WAEMU } & & & 2.532 & 2.353 & \\
\hline & & & $(3.08)^{\star \star}$ & $(3.28)^{\star *}$ & \\
\hline \multirow[t]{2}{*}{ CEMAC } & & & 2.887 & 3.400 & \\
\hline & & & $(2.82)^{\star \star}$ & $(3.41)^{\star \star}$ & \\
\hline \multirow[t]{2}{*}{ EAC } & & & 3.324 & 3.471 & \\
\hline & & & $(1.62)$ & $(1.70)$ & \\
\hline \multirow[t]{2}{*}{ ECOWAS } & & & -0.766 & & \\
\hline & & & $(1.18)$ & & \\
\hline \multirow[t]{2}{*}{ SADC } & & & 0.235 & & \\
\hline & & & $(0.36)$ & & \\
\hline \multirow[t]{2}{*}{ COMESA } & & & -1.495 & & \\
\hline & & & $(3.02)^{\star \star}$ & & \\
\hline \multirow[t]{2}{*}{ Constant } & -32.284 & -44.482 & -48.982 & -51.153 & -50.776 \\
\hline & $(7.28)^{\star \star}$ & $(9.44)^{\star \star}$ & $(9.79)^{\star \star}$ & $(10.45)^{\star \star}$ & $(10.44)^{\star \star}$ \\
\hline Observations & 1128 & 1128 & 1128 & 1128 & 1128 \\
\hline R-squared & 0.36 & 0.38 & 0.39 & 0.39 & 0.39 \\
\hline
\end{tabular}

Absolute value of $t$ statistics in parentheses

* significant at $5 \%$; ** significant at $1 \%$

Regional Trade Agreements (Country Membership in Appendix Table A7)

$\begin{array}{lll}\text { WAEMU } & = & \text { West African Economic and Monetary Union } \\ \text { CEMAC } & = & \text { Economic and Monetary Community of Central Africa } \\ \text { EAC } & = & \text { East African Community } \\ \text { COMESA } & = & \text { Common Market for Eastern and Southern Africa } \\ \text { ECOWAS } & = & \text { Economic Community of West African States } \\ \text { SADC } & = & \text { Southern African Development Community }\end{array}$


marginally significant. ${ }^{22}$ In contrast, none of the broader, more recent agreements has a positive, significant elasticity, and two - for ECOWAS and COMESA - have perverse signs. ${ }^{23}$ For our baseline impact simulations, we use the results in column (5), which control for membership in the three strongest trade agreements.

\subsection{Calibration of the Inter-City Gravity Model}

For each city pair in the network, gravity model estimation of trade flows requires four pieces of information: the economic scales of the two cities, the network distance between them, and the quality of the connecting roads. To proxy economic scale, we multiply the population of each city by national GDP per capita at purchasing power parity for 2001 (the most recent year for which comprehensive Sub-Saharan income data are available). We calculate inter-city distances in the network using our spatial network analysis model (see Figure 2), and index inter-city road quality using the minimum quality for transit countries. Then we use the parameter estimates from column (5), Table 5 to estimate trade volumes for 3,403 city pairs: ${ }^{24}$

(4) $\hat{T}_{i j}=K \frac{A_{i j}^{2.74} E_{i}^{1.71} M_{j}^{1.44} q_{i j}^{1.93}}{d_{i j}^{2.10}}$

where $\mathrm{T}_{\mathrm{ij}}=$ Trade volume between exporter $\mathrm{i}$ and importer $\mathrm{j}$

$\mathrm{K}=\mathrm{A}$ valuation constant

$\mathrm{A}_{\mathrm{ij}}=$ Membership in WAEMU, CEMAC or EAC ( $1=$ exporter and importer both members of the same agreement)

$\mathrm{E}_{\mathrm{i}}=$ Exporter economic scale

$\mathrm{M}_{\mathrm{j}}=$ Importer economic scale

$\mathrm{q}_{\mathrm{ij}}=$ Quality index for the road joining cities $\mathrm{i}$ and $\mathrm{j}$

$\mathrm{d}_{\mathrm{ij}}=$ Road distance between cities $\mathrm{i}$ and $\mathrm{j}$

\footnotetext{
22 Formally, rejection of zero effect with only $90 \%$ confidence.

23 The negative, significant result for COMESA appears in the reported regression, which is based on minimum inter-city road quality. The result is still negative, but insignificant, in the corresponding regression that is based on average inter-city road quality.

${ }^{24}$ This involves 6,806 calculations, since each city plays two roles (exporter, importer) in each pair. Two sets of calculations are necessary because parameter estimates for importers and exporters are not identical. We exclude 6 countries from the analysis because data for trade and other variables are missing: Botswana, Lesotho, Namibia, Swaziland, Somalia and Liberia.
} 
Arbitrarily setting $\mathrm{K}=1$, we use equation (4) to compute pre-upgrade trade flows as index numbers. We add all index numbers for cities in different countries, and divide the result into IMFDOT's total inter-country trade value. This produces a K-value for equation (4) that translates trade index numbers for city pairs into internally-consistent trade values.

We recognize that this K-value provides only an approximation, because neither our econometric results nor our inter-city trade simulations explicitly allow for modal alternatives (e.g., rail, ocean freight). Railroad connections are probably not important for the analysis, since they are sparse outside the Southern African Customs Union countries (whose inter-country trade is not captured by the IMFDOT data). ${ }^{25}$ Within Sub-Saharan Africa, intra-regional sea freight is potentially more significant, although its importance is considered relatively minor by African transport experts whom we have consulted. $^{26}$

Exclusion of alternate modes has probably reduced the explanatory power of our regressions (our $\mathrm{R}^{2}$ values are in the range .36 - .40). However, our estimated road quality and distance parameters do incorporate potential diversion to alternate modes, because our regressions are fitted to total trade data for partner countries. In summary, we believe that index-number translation via our K-value can provide useful insights about the potential value of road quality improvements between cities, countries and regions.

${ }^{25}$ Most rail lines in Sub-Saharan Africa have been constructed to bring raw materials from the interior to the coast for export. This paper analyses interior trade among African states, so we believe that exclusion of rail lines is not a source of significant error. In the future, inclusion of rail traffic will become important if more inter-country rail lines develop outside of southern Africa.

${ }^{26}$ We have consulted with the following experts, who are unanimous in attributing little importance to ocean transport among Sub-Saharan countries unless they are widely separated: Jan Hoffmann, Trade Facilitation Section, UNCTAD; Marc Juhel, Acting Sector Manager, Transport Unit, and Brad Julian, Port and Maritime Transport Specialist, Transport and Urban Development Department, World Bank; Simon Pitout, Manager, APM Terminals Africa regional office, Cape Town, South Africa. 


\subsection{Road Network Upgrading and Trade Expansion}

We simulate road network improvement by increasing all link quality indices to a minimum level of 45, which lies between the current index values for Zimbabwe and The Gambia (Table 2). While this would represent a great improvement for many links, we believe that it is a feasible target (see the discussion of costs in Section 5).

\section{Econometric Projection}

For Sub-Saharan Africa as a whole, we can use our econometric results to estimate the overall trade impact of road network upgrading. After estimating equation (5) in Table 5, we re-set all road quality indices to the minimum value of $45,{ }^{27}$ project the resulting logarithmic values for inter-country trade, transform the projections to exponentials, and calculate the sum of projections. Table 6 presents the results for current trade and projected trade after the network upgrade. We also include alternative projections, bounded by the projection standard error.

Total trade (as an annual average) in the IMFDOT data is \$US 10.1 billion for the period 2000-2003. After we upgrade all network links, projected trade increases by $\$ 19.7$ billion, to $\$ 29.8$ billion. Given the projection standard error, we compute low- and highrange projections as $\$ 16.3$ billion (an increase of $\$ 6.2$ billion) and $\$ 55.4$ billion (an increase of $\$ 45.3$ billion). In all cases, the projected impact of network upgrading is a large increase in overland trade in Sub-Saharan Africa.

Table 6: Current and Projected Trade: Econometric Results (\$US Million)

\begin{tabular}{|l|c|c|c|c|c|}
\hline & $\begin{array}{c}\text { Avg. Trade, } \\
2000-03\end{array}$ & $\begin{array}{c}\text { ProjectedTrade } \\
\text { After Upgrade } \\
\text { (Baseline) }\end{array}$ & Change & $\begin{array}{c}\text { Projected Trade } \\
\text { After Upgrade } \\
(-1 \text { Std. Error.) }\end{array}$ & $\begin{array}{c}\text { Projected Trade } \\
\text { After Upgrade } \\
(+1 \text { Std. Error })\end{array}$ \\
\hline Total & 10,121 & 29,809 & 19,688 & 16,357 & 55,463 \\
\hline
\end{tabular}

27 We retain the higher values for South Africa (100), Botswana (87.5) and Zimbabwe (50.0). 


\section{Gravity Model Simulation}

For each city pair, we use equation (4) to predict trade before and after road network upgrading. We compute ex-ante values for city-to-city trade, aggregate to country-to-country totals, and standardize to intercountry value totals from the IMFDOT data. To compute ex-post values, we upgrade minimum road link quality to 45 (intermediate between Zimbabwe and The Gambia) for all city pairs, re-compute intercity and intercountry index values, and standardize to the projected intercountry value totals from our econometric analysis of the IMFDOT data.

Our comparative results for the current and upgraded networks provide estimates of trade expansion for 77 cities, 36 countries, and 5 regions (West, Central, East, Southern and South $\mathrm{Africa}^{28}$ ). Table 7 displays regional values for current trade, estimated values after network upgrading, and changes. ${ }^{29}$ Total within-region trade grows by $\$ 11.1$ billion, with large gains in West Africa (\$4.5 billion), Central Africa ( $\$ 1.2$ billion), and East Africa ( $\$ 5.4$ billion). Total cross-region trade grows by $\$ 8.6$ billion, with $\$ 1.6$ billion attributable to expanded trade among West, Central and East Africa, $\$ 5.3$ billion to trade expansion between South Africa and West, Central and East Africa; \$224 million to expanded trade between Southern Africa and West, Central and East Africa; and \$1.4 billion to trade growth between Southern Africa and South Africa.

\footnotetext{
${ }^{28}$ Data problems prevent inclusion of cities in Botswana, Lesotho, Namibia, Swaziland, Liberia and Somalia. The other countries are grouped into regions as follows:

West: Benin, Burkina Faso, Chad, Cote d'Ivoire, The Gambia, Ghana, Guinea, Guinea-Bissau, Mali, Mauritania, Niger, Nigeria, Senegal, Sierra Leone, Togo

Central: Angola, Burundi, Cameroon, Central African Republic, D.R. Congo, Gabon, Rep. Congo, Rwanda, Zambia

East: $\quad$ Djibouti, Eritrea, Ethiopia, Kenya, Malawi, Sudan, Tanzania, Uganda

Southern: Mozambique, Zimbabwe

South: South Africa

29 Trade volume within South Africa remains the same, because current road quality (100) is already greater than the upgrading target for other regions.
} 
Appendix Table A2 provides an impact assessment at the country level, sorted regionally by percent change. Current trade summarizes IMFDOT data for 2000-03; upgraded trade reflects the change attributable to road network improvement. In West and Central Africa, predicted trade growth is very rapid in several coastal states near Nigeria (Benin (436\%), Togo (294\%), Ghana (223\%), Cameroon (264\%)), as well as countries that have been largely isolated by bad roads (e.g. Chad (507\%), Central African Rebublic (445\%), Sudan (1,027\%). The model predicts similar overland trade growth for Angola, Congo and Democratic Republic of Congo. However, their predicted growth rates in Table A2 are smaller because current export values are inflated by bulk minerals whose enclave production and export (by rail or ship) does not depend on road quality. In Southern Africa, road upgrading induces substantial trade expansion for Mozambique (168\%) because of its proximity to the South African market. Predicted expansion for Zimbabwe (15\%) is very modest because its road connections to most trading partners already meet the standard for Africa-wide network upgrading.

Appendix Table A3 presents results at the city level, sorted by region. Differences for cities in the same country reflect the differential impact of road quality improvements throughout the network. For example, trade growth in Nigeria varies from $850 \%$ for Maiduguri to $167 \%$ for Iwo. 
Table 7: Estimated Interregional Trade Volume Effect of Road Network Upgrading (\$US Million) ${ }^{30}$

\begin{tabular}{|c|c|c|c|}
\hline Regional Pair & $\begin{array}{c}\text { Current } \\
\text { Network } \\
\text { Trade }\end{array}$ & $\begin{array}{l}\text { Upgraded } \\
\text { Network } \\
\text { Trade }\end{array}$ & Change \\
\hline West & $2,838.1$ & $7,300.7$ & $4,462.6$ \\
\hline Central & 647.3 & $1,593.1$ & 945.8 \\
\hline West & 23.1 & 437.6 & 414.5 \\
\hline Southern & 4.2 & 50.6 & 46.4 \\
\hline South & 870.4 & $2,301.4$ & $1,431.0$ \\
\hline Central Central & 199.6 & $1,361.6$ & $1,162.0$ \\
\hline Central East & 308.1 & 590.4 & 282.3 \\
\hline Central $\quad$ Southern & 133.3 & 215.5 & 82.2 \\
\hline Central South & $1,390.2$ & $3,093.1$ & $1,702.9$ \\
\hline East & 724.0 & $6,169.8$ & $5,445.8$ \\
\hline Southern & 101.2 & 196.3 & 95.1 \\
\hline South & 871.3 & $3,010.3$ & $2,139.0$ \\
\hline Southern Southern & 142.6 & 190.3 & 47.7 \\
\hline Southern South & $1,867.9$ & $3,298.4$ & $1,430.5$ \\
\hline \multicolumn{4}{|l|}{ Totals } \\
\hline Within Regions & $3,904.3$ & $15,022.4$ & $11,118.1$ \\
\hline Across Regions & $6,217.0$ & $14,786.7$ & $8,569.7$ \\
\hline $\begin{array}{l}\text { Among West, Central, } \\
\text { East Africa }\end{array}$ & 978.5 & $2,621.1$ & $1,642.6$ \\
\hline $\begin{array}{l}\text { West, Central, East Africa } \\
\text { with South Africa }\end{array}$ & $3,131.9$ & $8,404.8$ & $5,272.9$ \\
\hline $\begin{array}{l}\text { West, Central, East Africa } \\
\text { with Southern Africa }\end{array}$ & 238.7 & 462.4 & 223.7 \\
\hline $\begin{array}{l}\text { Southern Africa with } \\
\text { South Africa }\end{array}$ & $1,867.9$ & $3,298.4$ & $1,430.5$ \\
\hline Total & $10,121.3$ & $29,809.1$ & $19,687.8$ \\
\hline
\end{tabular}

\subsection{Implications}

Our results highlight the importance of a network perspective in evaluating road

investment opportunities in Sub-Saharan Africa. The overall implications are illustrated by Figure 3, which presents two types of information: country road-quality indices and network road links, size-graded to reflect frequency of use by the 3,403 minimumdistance routes in our analysis. Figure 3 shows that the minimum-distance routes joining

\footnotetext{
${ }^{30}$ By construction, as we have previously explained, total simulated trade prior to upgrading in Table 7 is the same as the calculated total for the IMFDOT data in Table 6. Total simulated trade in Table 7 after upgrading ( $\$ 29.8$ billion) also matches the total econometric projection reported in Table 6
} 
West Africa to East, Southern and South Africa are divided between two corridors with low road transport quality indices (RQI see Table 2). The first passes through Cameroon (RQI 18.4), Gabon (19.2), Congo (Rep.) (13.6), Congo (D.R.) (3.8) and Angola (15.8). The second passes through the four countries with the lowest road quality indices in Africa: Chad (1.8), Congo D.R. (3.8), Central African Republic (4.4) and Tanzania (6.2). The result for this route is a low-level equilibrium trap. Interregional traffic is negligible because the roads in these countries are so poor. At the same time, poverty in the areas traversed by the roads is increased by their isolation. Under these conditions, our results suggest that network upgrading, including simultaneous improvement of road links in all four countries, would promote a very large expansion of local and interregional trade. Local improvements in one or two countries will not overcome the low-level trap, because risk-averse shippers will continue to judge the weakest link in assessing the profitability of interregional shipments.

A useful illustration is provided by estimated traffic volume in the Democratic Republic of Congo and, more specifically, on the road from Kisangani, in the northeast D.R. of Congo, to Bangui, Central African Republic. At present, road conditions are so poor that estimated traffic is very small; cost-benefit analysis based on local traffic counts would probably not justify the use of scarce resources to upgrade this road. ${ }^{31}$ From a continental perspective, however, the situation looks very different. Of the 3,403 city pairs in our analysis, minimum-distance routes for 655 pairs include the road from Bangui to Kisangani (see Figure 3). As the enlarged component of Figure 3 shows, this is part of a link between West and Southern Africa in our configuration of the network.

${ }^{31}$ Salopek (2005) characterizes the roads of the northeast Congo D.R. as follows: "What words can be uttered about these roads? Clogged with mud, strangled by bush, reduced in many cases to absurd footpaths ... The roads are no longer roads." (p. 84) 
After upgrading, the baseline gravity model estimates that goods traded via this route would expand from a current value of \$US 15.9 million to \$US 142 million: a 793\% increase.

Figure 3: Road Network Links: Current Quality and Potential Significance (West - Southern Africa Link Enlarged)

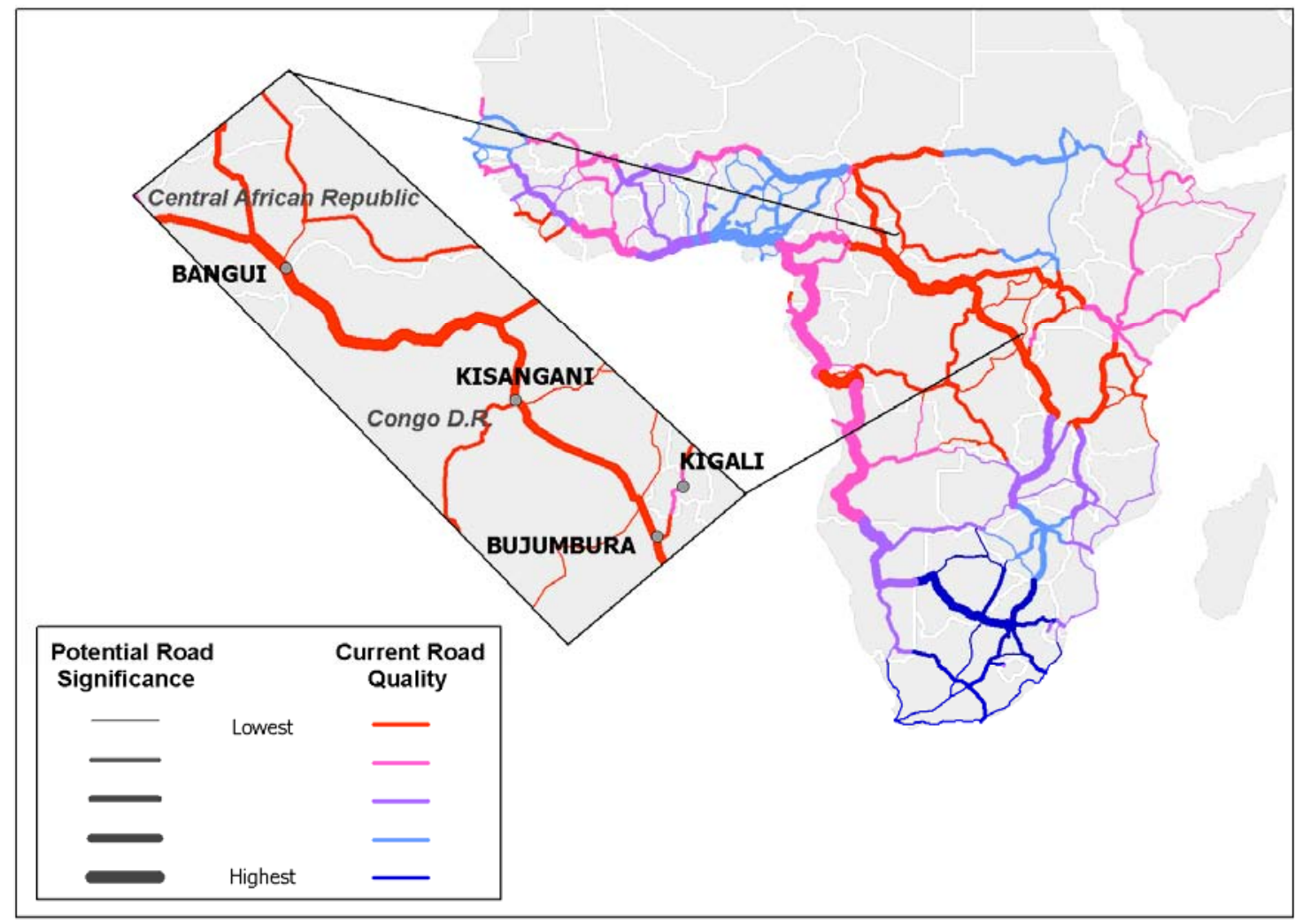

Figures 4 and 5 extend the results from one route to the entire network. Figure 4 displays estimated traffic volumes before upgrading, while Figure 5 displays percent changes in volume after upgrading. In Figure 4, the highest volumes are along the main western corridor (from Senegal to South Africa) and within southern Africa. Upgrading generates a striking pattern of continental change (Figure 5), with high volume growth rates in the interior regions of West, Central and East Africa, as well as along the main arteries that connect these regions. These high percentage changes in isolated regions of the interior may arguably have greater growth inducing and poverty reducing effects than larger volume changes in regions that are already well integrated. 
Figure 4: Current Trade Estimates for the Network (\$US Million)

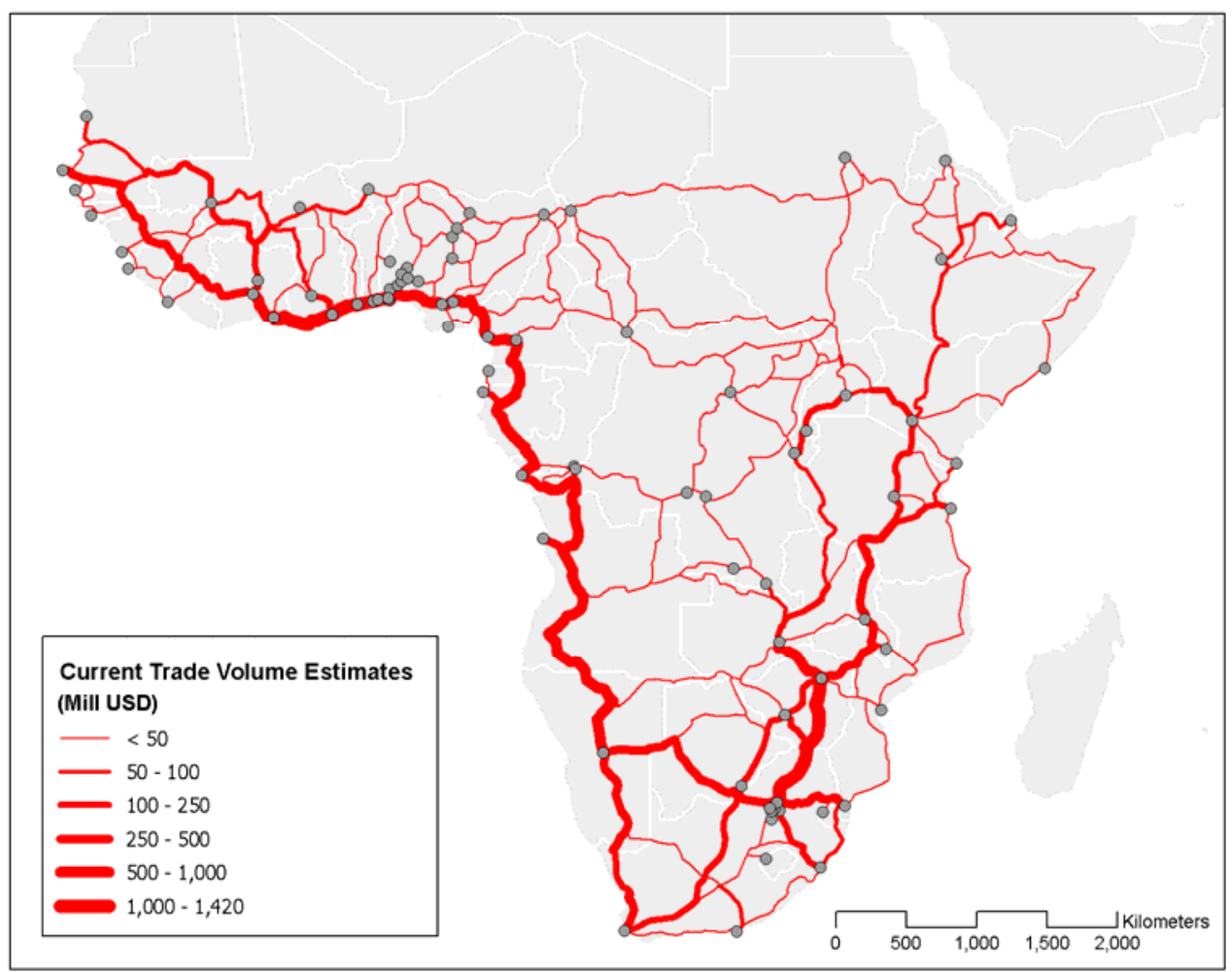

Figure 5: Percent Changes in Trade after Road Upgrading

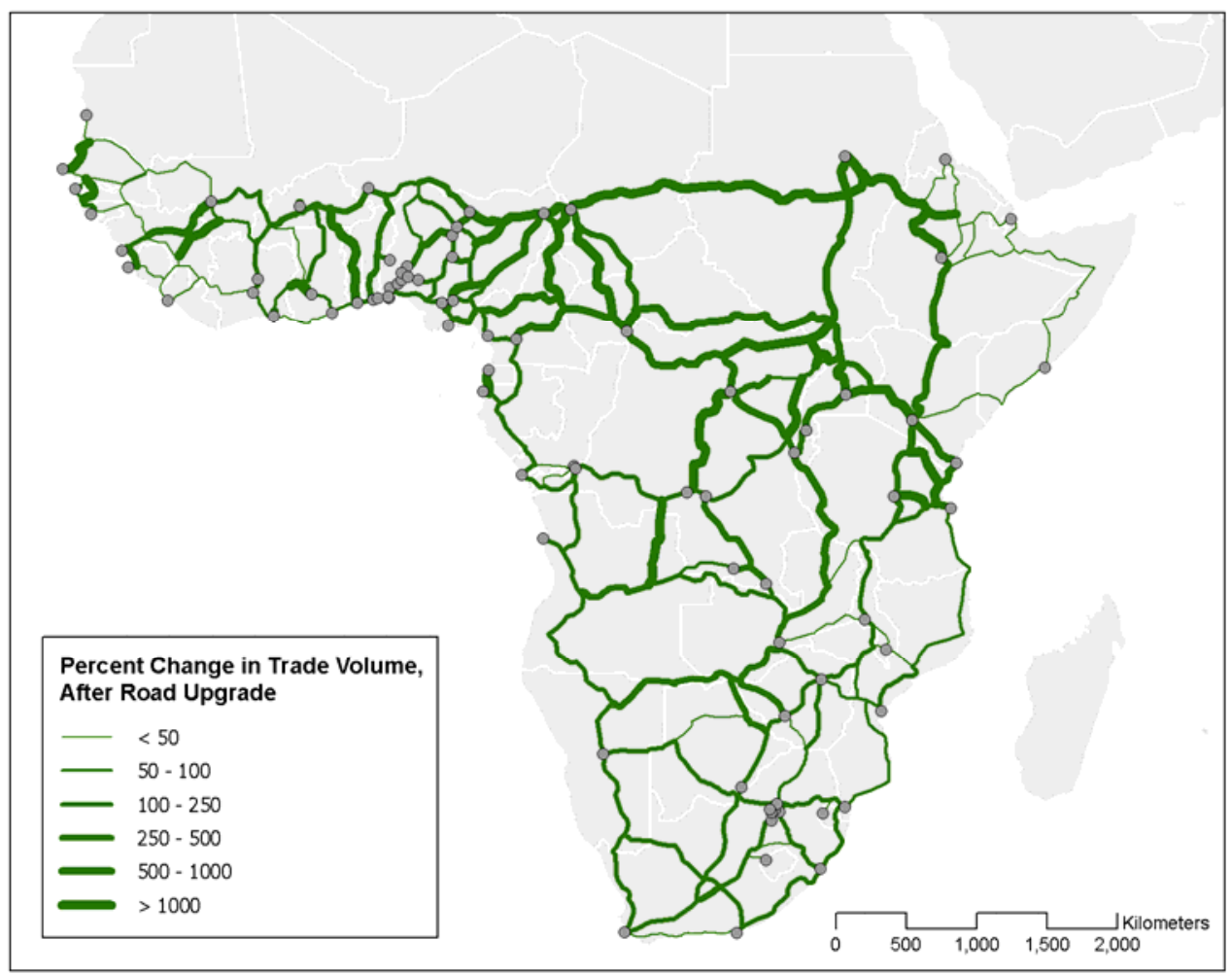


Among all road links that form the Trans-African network, median traffic growth after upgrading is $182 \%$ at the median, $447 \%$ at the $75^{\text {th }}$ percentile, and $1,295 \%$ at the $90^{\text {th }}$ percentile.

\section{Network Upgrading Cost}

We have used the World Bank's Road Cost Knowledge System (ROCKS) to estimate the costs of upgrading and maintaining the 83-city road network described in this paper. ${ }^{32}$ Table 8 provides detailed information from ROCKS for 470 upgrading and maintenance projects in Sub-Saharan Africa. ${ }^{33}$ Estimated unit costs (\$US/kilometer) vary widely by type, both within and across categories. For 170 upgrading projects, the median unit cost is approximately $\$ 127,800$ per kilometer (Table 9), but median cost by work type varies from $\$ 55,000 / \mathrm{km}$ for asphalt mix resurfacing to over $\$ 1$ million $/ \mathrm{km}$ for new highway construction. For 300 maintenance projects, with median unit cost of $\$ 5,600$ per kilometer, work types vary from $\$ 500 / \mathrm{km}$ for grading to over $\$ 20,000 / \mathrm{km}$ for surface treatment resurfacing. Table 10 provides information on the scale of the network to be upgraded and maintained. Its total length, calculated from the geographic database of road links, is 108,820 kilometers, with well-maintained, paved highways in South Africa accounting for 9,802 kilometers. West Africa has $32,248 \mathrm{~km}$ in the network, Central Africa 29,274, East Africa 24,146 and Southern Africa 13,350.

Sub-Saharan countries exhibit wide variations in institutional, economic, topographic and climatic factors that may have significant effects on the cost of road

${ }^{32}$ The ROCKS website address is http://www.worldbank.org/transport/roads/rd tools/rocks main.htm

33 African countries in the ROCKS road project cost database include:

West Africa: Chad, Ghana, Guinea, Mali, Nigeria, Sierra Leone

Central Africa: Zambia

East Africa: Madagascar, Malawi, Tanzania, Uganda

Southern Africa: Botswana, Zimbabwe 
upgrading and maintenance. To provide the best feasible estimate of network improvement costs by area, we need to tailor our unit cost estimates to local conditions as closely as possible. We focus at the country level in this paper, since the ROCKS data and information on road cost determinants are currently available at that level.

Table 8: Unit Cost Statistics, World Bank Road Projects in Sub-Saharan Africa (\$’000/km)

\begin{tabular}{|c|c|c|c|c|c|c|c|}
\hline \multirow{2}{*}{ Work Type } & \multirow{2}{*}{ Class } & \multirow[b]{2}{*}{ \# } & \multicolumn{5}{|c|}{ Percentiles } \\
\hline & & & 10 & 25 & 50 & 75 & 90 \\
\hline Grading & Maintenance & 3 & 0.2 & 0.2 & 0.5 & 0.9 & 0.9 \\
\hline Routine Maintenance & Maintenance & 22 & 0.6 & 1.7 & 2.0 & 3.0 & 3.5 \\
\hline Unsealed Preventive Maintenance & Maintenance & 98 & 2.8 & 3.3 & 4.3 & 5.1 & 5.7 \\
\hline Bituminous Pavement Preventive Treatment & Maintenance & 39 & 2.3 & 3.3 & 5.0 & 7.7 & 18.8 \\
\hline Gravel Resurfacing & Maintenance & 112 & 3.9 & 7.1 & 10.1 & 17.4 & 37.9 \\
\hline Surface Treatment Resurfacing & Maintenance & 26 & 13.0 & 18.4 & 20.3 & 32.2 & 38.5 \\
\hline Asphalt Mix Resurfacing & Upgrading & 27 & 22.7 & 39.2 & 54.7 & 70.4 & 95.1 \\
\hline Reconstruction & Upgrading & 88 & 22.8 & 78.6 & 128.9 & 218.1 & 333.8 \\
\hline Strengthening & Upgrading & 14 & 80.8 & 103.0 & 130.3 & 162.1 & 203.7 \\
\hline Partial Widening & Upgrading & 1 & 136.0 & 136.0 & 136.0 & 136.0 & 136.0 \\
\hline Upgrading & Upgrading & 35 & 53.0 & 109.1 & 262.5 & 331.1 & 473.3 \\
\hline New Two-Lane Highway & Upgrading & 2 & 660.2 & 660.2 & $1,023.4$ & $1,386.5$ & $1,386.5$ \\
\hline Widening and Reconstruction & Upgrading & 3 & 989.1 & 989.1 & $1,331.1$ & $1,568.4$ & $1,568.4$ \\
\hline Total & & 470 & & & & & \\
\hline
\end{tabular}

Table 9: Unit Cost Statistics by Activity Class (\$’000/km)

\begin{tabular}{|l|c|c|c|c|c|c|}
\hline \multirow{2}{*}{ Activity Class } & \multirow{2}{*}{$\#$} & \multicolumn{5}{|c|}{ Percentiles } \\
\cline { 3 - 7 } & & 10 & 25 & 50 & 75 & 90 \\
\hline Maintenance & 300 & 2.3 & 3.6 & 5.6 & 12.7 & 24.7 \\
\hline Upgrading & 170 & 24.0 & 57.7 & 127.8 & 243.8 & 391.6 \\
\hline
\end{tabular}


Table 10: Sub-Saharan Road Network Length by Region

\begin{tabular}{|l|r|}
\hline Region & $\begin{array}{c}\text { Network } \\
\text { Length } \\
(\mathrm{km})\end{array}$ \\
\hline West & 32,248 \\
\hline Central & 29,274 \\
\hline East & 24,146 \\
\hline Southern & 13,350 \\
\hline South & 9,802 \\
\hline Total & 108,820 \\
\hline
\end{tabular}

\subsection{Cost Function Estimation: Specification and Data}

To assess inter-country variability in upgrading and maintenance costs, we fit the following unit cost function to the ROCKS data for Sub-Saharan Africa:

(4) $\log C_{i j}=\beta_{0}+\beta_{1} \log R_{i}+\beta_{2} P_{i}+\beta_{3} \log Y_{i}+\beta_{4} G_{i}+\sum_{j} \theta_{j} U_{j}+\sum_{k} \delta_{k} M_{k}+\varepsilon_{i j}$

where $C_{i j}=$ Unit cost of project-type $\mathrm{j}$ in country $\mathrm{i}$

$\mathrm{R}_{\mathrm{i}}=$ Rainfall intensity around the road network of country $\mathrm{i}$

$\mathrm{P}_{\mathrm{i}}=$ Percent of roads in country $\mathrm{i}$ that are paved

$\mathrm{Y}_{\mathrm{i}}=$ Income per capita in country $\mathrm{i}$

$\mathrm{G}_{\mathrm{i}}=$ Governance quality in country $\mathrm{i}$

$\mathrm{U}_{\mathrm{j}}=$ Upgrading

Widening and Reconstruction

Reconstruction

New 2-Lane Highway

Strengthening

Partial Widening

Asphalt Mix Resurfacing

$\mathrm{M}_{\mathrm{k}}=$ Gravel Resurfacing

Surface Treatment Resurfacing

Bituminous Pavement Preventive Treatment

Unsealed Preventive Treatment

Routine Maintenance

Grading

Roads are more expensive to build and maintain in high-rainfall areas, ceteris

paribus. Many countries in Sub-Saharan Africa are large and climatically diverse, so

national average rainfall provides a very crude approximation to conditions in specific

areas. We believe that rainfall in the areas traversed by our network links provides a 
closer approximation, since they are primary roads connecting the major cities of each country with each other, and with the major cities of other countries. Not all World Bank projects have focused on primary roads, but it seems reasonable to assume that most of them have, in light of generally-poor road conditions and the scarcity of resources for improvement. Accordingly, we use GIS to overlay the road network with an African rainfall map and compute rainfall intensity (average $\mathrm{mm}$. of rainfall on days that it rains $^{34}$ ) for the area surrounding each link in the network. Then we compute country mean rainfall as the weighted mean of link-specific means, where the weights are proportional to link distances.

We hypothesize that incremental upgrading and maintenance costs are lower for countries where current road conditions are relatively good. We proxy this factor using countries' percent of roads that are paved from the World Bank's World Development Indicators. The available data are spotty and exhibit significant variability from year to year, so we have chosen a conservative approach: From the WDI estimates of percent paved for the period 1997-2002 (the latest year available), we use the minimum value as our estimate. We use percent paved rather than log percent paved because the former is already scale-invariant.

African road projects are labor-intensive, so local wages should be a significant determinant of upgrading and maintenance costs. To proxy relative wages, we use mean GDP per capita (in \$US) at purchasing power parity for the period 2000-2003, from the World Bank's World Development Indicators. To control for possible effects of governance quality (including corruption) on cost, we employ an index of transparency, accountability and corruption from the World Bank's 2004 database for Country Policy

\footnotetext{
${ }^{34}$ This analysis is based on data from the Climatic Research Unit, University of East Anglia, UK.
} 
and Institutional Assessments (CPIA). We employ the linear index in the reported regressions (Table 12); the log index gives the same (insignificant) result. We also introduce dummy variable controls for regions, to account for unobservable geographic factors, and for project types.

\subsection{Cost Function Estimation: Results}

Table 12 presents estimation results for the unit cost model. We discuss the results in column (2), which excludes governance because the latter is insignificant in column (1). The estimated parameter for rainfall has the expected sign, is highly significant, and indicates an important impact: Estimated unit costs rise about $1.4 \%$ for each $1 \%$ increase in rainfall intensity. The estimated elasticity for income per capita, our wage proxy, is also large and highly significant. Our results suggest that a 1\% increase in income per capita increases road improvement costs by $0.75 \%$. Percent paved is also highly significant, with a decrease of about 0.05 in the log of unit cost for every unit increase in percent paved. Given the strength of these results, we would expect significant intercountry differences in unit improvement costs, because Sub-Saharan countries exhibit wide variation in rainfall intensity, percent of roads paved and income per capita. As Table 11 shows, rainfall intensity varies 3 -fold, percent paved over 60-fold, and income per capita about 20 -fold in the countries connected by the network.

Table 11: Variations in Road Cost Determinants: Countries in Sub-Saharan Africa

\begin{tabular}{|l|c|c|c|c|c|}
\hline Variable & Min & Q1 & Median & Q3 & Max \\
\hline Rainfall Intensity (mm./day) & 6.2 & 7.9 & 10.6 & 13.5 & 18.9 \\
\hline Percent of Roads Paved & 0.8 & 8.3 & 12.3 & 20.0 & 60.0 \\
\hline $\begin{array}{l}\text { Income Per Capita } \\
\text { (\$US 2001, PPP) }\end{array}$ & 470 & 800 & 1,099 & 1,932 & 9,593 \\
\hline
\end{tabular}


Our results indicate a pronounced cost effect in West Africa (significantly lower unit costs than the other regions), and the same wide dispersion of unit costs by work type that we have already observed in Table 8 . The results suggest that, once we control for country characteristics, unit costs for upgrading projects are significantly different only for two types: New two-lane highway construction and widening and reconstruction. On the other hand, unit costs remain highly differentiated for maintenance categories. As in Table 8, grading is lowest-cost in this category and surface treatment resurfacing highest-cost, ceteris paribus.

Using the results in Table 12 and our country database, we project benchmark unit cost estimates for each country in the network. We also subtract and add standard projection errors to the benchmark projections to obtain low- and high-range projections. We use country-specific measures for rainfall intensity, percent paved and income per capita. For work types, we use the same mix that characterizes the projects in the ROCKS database. We project unit costs for upgrading and maintenance separately. For upgrading, we use each relevant work type's share in 170 ROCKS upgrading projects as the multiplicative weight for its estimated dummy variable parameter in Table 12. For maintenance, we use each work type's share in 300 ROCKS maintenance projects as the multiplicative weight for its parameter.

Complete unit cost results are included in Appendix Tables A4 (upgrading) and A5 (maintenance). We summarize the results by work category and region in Table 13, which indicates substantial regional variation in unit costs. For upgrading, the median unit cost is $\$ 167,700 / \mathrm{km}$; regional costs vary from $\$ 135,000 / \mathrm{km}$ to $\$ 418,000 / \mathrm{km}$. Within regions, there is also wide variation. The maintenance results replicate this 
Table 12: Determinants of Unit Costs for Road Upgrading and Maintenance

Dependent Variable: Log Road Project Unit Cost (\$US/Km) from ROCKS

Log Mean Rainfall

1.791

1.355

$(2.44)^{\star}$

$(2.32)^{*}$

Percent Paved

$-0.038$

$-0.046$

$(2.28)^{\star}$

$(4.58)^{\star \star}$

Log Income Per Capita

0.709

0.749

$(2.42)^{\star}$

$(2.67)^{\star \star}$

Governance

0.309

(1.23)

West Africa

$-0.849$

$-0.730$

(1.32)

$(6.24)^{\star \star}$

Central Africa

$-0.339$

(0.49)

East Africa

0.139

(0.19)

\section{Upgrading Categories}

New 2-Lane Highway

2.057

$(2.58)^{\star}$

Widening and Reconstruction

1.503

$(1.99)^{\star}$

Upgrading

$-0.154$

$(0.23)$

Strengthening

$-0.306$

(0.45)

Reconstruction

Asphalt Resurfacing

$-0.341$

(0.53)

$-1.042$

(1.58)

2.111

$(2.66)^{\star \star}$

1.416

(1.88)

$-0.118$

(0.18)

$-0.329$

(0.49)

$-0.337$

(0.52)

$-1.037$

Maintenance Categories

Surface Treatment Resurfacing

$-1.892$

$(2.87)^{\star \star}$

$-2.785$

Gravel Resurfacing

$(4.29)^{\star \star}$

$-3.278$

$(5.01)^{\star *}$

$-4.389$

$(6.71)^{\star *}$

$-4.876$

$(7.35)^{\star \star}$

$-5.899$

$(7.81)^{\star \star}$

(1.58)

Grading

3.306

(0.94)

$-1.906$

$(2.89)^{\star \star}$

$-2.782$

$(4.28)^{\star \star}$

$-3.281$

$(5.02)^{\star \star}$

$-4.375$

$(6.69)^{\star \star}$

$-4.877$

$(7.35)^{\star \star}$

$-5.893$

$(7.80)^{\star \star}$

Constant

465

4.989

(1.63)

Observations

0.86

465

0.86

Absolute value of $t$ statistics in parentheses significant at $5 \%$; ** significant at $1 \%$ 
pattern: Median maintenance costs vary from $\$ 5,900 / \mathrm{km}$ in West Africa to $\$ 18,200 / \mathrm{km}$ in Central Africa. We should stress that these variations are projected for the same project mix in each region.

Table 13: Regional Variations in Projected Unit Costs (\$’000 US/km)

\begin{tabular}{|l|r|r|r|r|}
\hline \multicolumn{5}{|c|}{ Upgrading } \\
\hline Region & \multicolumn{1}{|c|}{ Min } & Median & \multicolumn{1}{c|}{ Max } \\
\hline West & 16 & 70.2 & 135.0 & 309.0 \\
\hline Central & 10 & 109.2 & 418.3 & $1,588.3$ \\
\hline East & 9 & 113.3 & 146.5 & 387.9 \\
\hline Southern & 7 & 80.0 & 189.7 & 621.9 \\
\hline Total & 42 & 70.2 & 167.7 & $1,588.3$ \\
\hline \multicolumn{5}{|c|}{ Maintenance } \\
\hline Region & $\mathrm{N}$ & Min & Median & Max \\
\hline West & 16 & 3.1 & 5.9 & 13.4 \\
\hline Central & 10 & 4.8 & 18.2 & 69.1 \\
\hline East & 9 & 4.9 & 6.4 & 16.9 \\
\hline Southern & 7 & 3.5 & 8.3 & 27.1 \\
\hline Total & 42 & 3.1 & 7.3 & 69.1 \\
\hline
\end{tabular}

Table 14: Projected Total Network Upgrading Costs

\begin{tabular}{|l|r|r|r|}
\hline Work Type & Benchmark & $\begin{array}{c}\text { LOW } \\
(-1 \text { SE) }\end{array}$ & $\begin{array}{c}\text { High } \\
(+1 \text { SE) }\end{array}$ \\
\hline $\begin{array}{l}\text { Upgrading } \\
\text { (\$US Billion) }\end{array}$ & 20,715 & 15,601 & 28,380 \\
\hline $\begin{array}{l}\text { Maintenance } \\
\text { (\$US Million) }\end{array}$ & 901 & 683 & 1,226 \\
\hline
\end{tabular}

Table 14 summarizes total cost results for our benchmark, high and low cases. For upgrading, our benchmark projection is $\$ 20.7$ billion, with standard error bounds at $\$ 15.6$ billion and $\$ 28.4$ billion. These estimates are roughly compatible with previous estimates by Heggie and Vickers (1998) for upgrading all Sub-Saharan roads currently classified as 
being in poor condition. ${ }^{35}$ For maintenance, our benchmark total annual cost estimate is

\$901 million, with standard error bounds at \$683 million and \$1.2 billion.

Table 15: Projection Ranges for Trade Expansion and Upgrade Costs

\begin{tabular}{|l|r|l|r|l|r|r|r|r|}
\hline $\begin{array}{c}\text { Trade } \\
\text { Category }\end{array}$ & $\begin{array}{c}\text { Annual } \\
\text { Trade } \\
\text { Growth } \\
\text { (\$Bill.) }\end{array}$ & $\begin{array}{c}\text { Upgrade } \\
\text { Cost } \\
\text { Category }\end{array}$ & $\begin{array}{c}\text { Upgrade } \\
\text { Cost } \\
\text { (\$Billion) }\end{array}$ & $\begin{array}{c}\text { Maint. Cost } \\
\text { Category }\end{array}$ & $\begin{array}{c}\text { Maint. } \\
\text { Cost } \\
\text { (\$Bill.) }\end{array}$ & $\begin{array}{c}\text { Total } \\
\text { Trade } \\
\text { Growth } \\
\text { (\$Bill.) }\end{array}$ & $\begin{array}{c}\text { Total } \\
\text { Cost } \\
\text { (\$Bill.) }\end{array}$ & $\begin{array}{c}\text { Net } \\
(\$ B \text { Bill.) }\end{array}$ \\
\hline Low & 6.2 & High & 28.4 & High & 1.2 & 77.5 & 43.4 & 34.1 \\
\hline Low & 6.2 & Benchmark & 20.7 & Benchmark & 0.9 & 77.5 & 32.0 & 45.6 \\
\hline Low & 6.2 & Low & 15.6 & Low & 0.7 & 77.5 & 24.4 & 53.2 \\
\hline Benchmark & 19.7 & High & 28.4 & High & 1.2 & 246.25 & 43.4 & 202.9 \\
\hline Benchmark & 19.7 & Benchmark & 20.7 & Benchmark & 0.9 & 246.25 & 32.0 & 214.3 \\
\hline Benchmark & 19.7 & Low & 15.6 & Low & 0.7 & 246.25 & 24.4 & 221.9 \\
\hline High & 45.3 & High & 28.4 & High & 1.2 & 566.25 & 43.4 & 522.9 \\
\hline High & 45.3 & Benchmark & 20.7 & Benchmark & 0.9 & 566.25 & 32.0 & 534.3 \\
\hline High & 45.3 & Low & 15.6 & Low & 0.7 & 566.25 & 24.4 & 541.9 \\
\hline
\end{tabular}

Table 15 combines projection ranges for trade expansion and upgrading costs in a composite assessment of benefits and costs. We allow for a 5-year upgrade period, and assume that road upgrading would have to be repeated after 10 years of continuous operation. Our benchmark estimates (fifth row) indicate trade expansion of $\$ 19.7$ billion per year, an initial upgrading cost of $\$ 20.7$ billion, and annual maintenance costs of $\$ 0.9$ billion. Assuming a 5-year upgrade period (with continuously increasing trade) and 10 years of operation, total trade expansion is $\$ 246.3$ billion over fifteen years, while total costs (initial upgrading and annual maintenance) are $\$ 32$ billion. Table 15 provides the full set of estimates associated with our standard error projection ranges. While the range of variation is wide, the basic conclusion seems clear. Given our econometricallyestimated parameters for existing trade flows and road costs in Africa, a feasible upgrade

${ }^{35}$ Heggie and Vickers estimate a cost of $\$ 43$ billion to fully restore all primary roads on the continent that are in poor condition. The roads considered in our paper comprise the minimum network needed to connect all capitals and major cities in Sub-Saharan Africa, not all primary roads on the continent. 
of the trans-African network generates trade flows that are far greater than the associated upgrade costs. We should stress that our benefit estimates are extremely conservative, since they do not include any inter-city trade expansion within countries (Nigeria alone has 18 cities in the network) or increased trade between Sub-Saharan countries and other parts of the world. Nor do they account for any induced growth from the expansion of inter-country trade. We conclude that the basic economics look very promising. In the next two sections, we turn our attention to the environmental and institutional implications of network upgrading.

\section{Potential Environmental Impacts}

Our results suggest that network upgrading would generate a very large increase in trade and, by implication, traffic volume on many of Africa's primary roads. Since Africa is also a repository for much of the world's biological diversity, we cannot ignore the potential implications of road upgrading for conservation. Figure 6 provides evidence on the conservation sensitivity of each link in the trans-African network. The underlying biodiversity information has been drawn from an extensive spatial database compiled by the Global Environment Facility and the World Bank's Development Research Group in collaboration with the World Conservation Union (IUCN). Pandey, et al. (2006) provide a complete description of the database, which contains the most recent information about the habitat ranges and conservation status of 5,327 amphibians, 4,612 mammals and 1,098 endangered birds. To index the differential conservation sensitivity of network

components, we overlay the species range maps with 50-km corridors around network links and compute total amphibians, mammals and endangered birds within each corridor. Figure 6 depicts the results in five categories, by species count. While the 
Figure 4: Biodiversity in Road Network Corridors

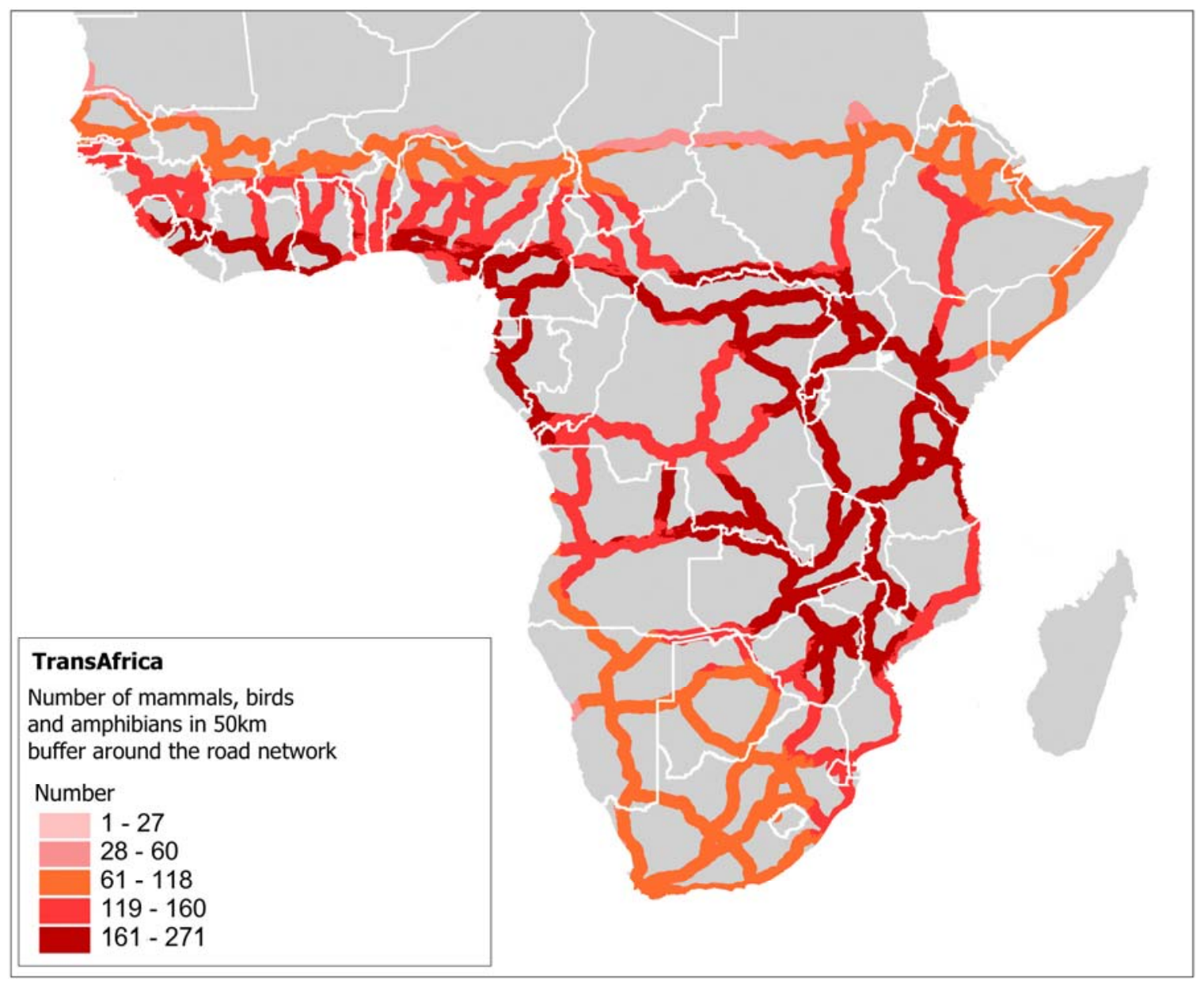

pattern of implied sensitivity is relatively complex, comparison of Figures 5 and 6 reveals an issue of potential concern: Many of the West, Central and East African network corridors with the greatest anticipated growth in traffic after upgrading are also corridors in the highest category of conservation sensitivity. We conclude that any broad-scale upgrading within or across regions will confront the biodiversity conservation problem. This result points to the inescapable need for conservation planning and investment as part of any road network upgrading strategy. 


\section{Implementation Issues, Costs and Local Employment Benefits}

The results in Section 4 indicate that coordinated upgrading of the Sub-Saharan road network is likely to generate a very large expansion of interregional trade. Piecemeal, local improvements do not have the same potential, because the cost calculations of interregional shippers will be dominated by conditions in the lowestquality network links. The success of upgrading would depend on smooth traffic flow over the whole network, with minimal delays at national borders and open roads within countries. We recognize that implementation of such a program would be difficult, but our results suggest that the potential payoff is sufficiently high to warrant a serious discussion.

In this section, we offer some preliminary thoughts about appropriate institutional arrangements and administrative measures, along with the associated costs. We present estimates of direct and indirect benefits for the rural poor generated by upgrading and maintaining the road system. We also provide rough estimates of the costs associated with administration of a trans-African network. We recognize the uncertainty in these estimates, but for the present purposes we are interested in orders of magnitude, not precise figures. We have already estimated maintenance costs from our econometric analysis of projects in the ROCKS database.

\subsection{Overall Organization and Financing.}

Coordinated upgrading and maintenance of the network could be accomplished by an all-Africa convention on overland trade, implemented in collaboration with multilateral and bilateral donors, that would cover 5 years of upgrading and 10 years of 
full operation. ${ }^{36}$ The agreement would ensure streamlined border procedures, finance and monitor needed repairs and maintenance, and implement measures to stop harassment of truckers for bribes at local road barriers. We should stress that donor support for this program would be strictly limited to the trans-African network links, which account for a modest part of primary and secondary road systems for most African countries. This limitation is necessary to preserve countries' incentive to use domestic resources for upgrading and maintaining their other roads. Existing national road funds would be wellspent on improving local access to the network on feeder roads, and the productivity of local funds would be greatly enhanced by the existence of the trans-African network.

\subsection{Monitoring Network Conditions}

Traffic conditions in the network could be monitored relatively easily by mobile inspection teams, supplemented by airborne surveillance. Strategically-located equipment pools would be needed for rapid repair of damaged roads and bridges. Network monitoring by an all-Africa inspection force would require financial support for vehicles, personnel and supplies. To approximate the associated costs, we have calculated annual support costs per person for six UN peacekeeping operations in Africa. ${ }^{37}$ These vary from $\$$ US 44,000 to $\$$ US 66,000 , with an average value of $\$ 54,000$.

Although the UN costs include vehicle support, we estimate conservatively by costing this separately. Under reasonable assumptions about vehicle monitoring range

\footnotetext{
${ }^{36}$ See also Simuyemba (2000), who proposes a series of Infrastructure Protocols as a basis for African regional integration,

${ }^{37}$ The UN operations are UMASIL (Sierra Leone); MUNOC (Congo D.R.); ONUB (Burundi); UNOCI (Cote d'Ivoire), UNMIL (Liberia); UNMEE (Ethiopia, Eritrea). Detailed calculations are available from the authors on request.
} 
and team size in a 90,000 km system, ${ }^{38}$ annual vehicle and personnel costs for road monitoring (700 vehicles, 7,000 people) are approximately \$US 400 million. Assuming 1,000 people for overhead support adds another $\$ 54$ million. We estimate the annual cost of complementary airborne surveillance at about $\$ 56$ million. ${ }^{39}$ To summarize, the approximate annual cost for the requisite road and airborne monitoring system is about $\$ 500$ million.

\subsection{Working with Roadside Communities}

A trans-African network cannot function properly if roadside communities constantly harass truckers for bribes. Under current conditions, local barricades are improvised "toll stations" for local police and other groups who have low wages (if any) and/or the power to extract payments from passing vehicles. Undoubtedly, these payments provide support for extended families in neighboring settlements, whose de facto local control will not change in the foreseeable future. Realistically, abutting settlements will only support barricade removal if they stand to gain from the change. For the trans-African network, the critical operational question is how to make barricade removal worth their while.

We believe that the requisite incentives would be provided by three factors. The first is employment and income generated by initial upgrading and continuous maintenance of the network, coupled with a clear prior understanding about barricade

$38150 \mathrm{~km} /$ day monitoring range and 10-person operational and support team per vehicle. Monitoring the whole system would require 700 vehicles, allowing for 100 spares. Associated monitoring personnel would number 7,000. We compute costs for a 90,000 km system on the assumption that South Africa and its neighboring states (principally Botswana) would maintain current road quality, which is above our target quality for the rest of the network.

${ }^{39}$ For airborne surveillance, we assume one helicopter pass per day over the entire network. This would require approximately 140 standard light utility helicopters with pilot and one crew member, carrying a unit cost of approximately $\$ 200,000$, operating cost of $\$ 100 /$ hour, a cruising speed of $150 \mathrm{~km} /$ hour, and operating range of $300 \mathrm{~km}$. We estimate the cost of this helicopter fleet at about $\$ 30$ million, with annualized costs (operations and 30\% replacement/year) of about $\$ 56$ million. 
removal for villages along the planned right-of-way. We estimate the potential

employment and income gains from the country-level upgrading and maintenance cost estimates in Appendix Tables A4 and A5. Drawing on results from a recent UNDP study of labor-intensive road construction in Mozambique (UNDP, 2002), we assume a 35\% labor share of total construction expenditure. Dividing the resulting wage bill by the annual wage per road worker, we arrive at estimated annual employment per country for initial upgrading and subsequent maintenance. ${ }^{40}$ To put the results in perspective, we also calculate populations for areas contiguous to the network in each country. ${ }^{41} \mathrm{We}$ present the employment and population results for all network countries in Appendix Table A6.

Our results indicate a variety of employment and income impacts, from modest to extremely large. Democratic Republic of Congo provides an illustration of large-scale benefit generation, with total network length of $12,184 \mathrm{~km}$, between 2,000 and 4,900 abutting settlements, and abutting population (within $5 \mathrm{~km}$ of the road) between 1 and 7.3 million. At estimated Congolese wages (\$500/year), network upgrading generates

\footnotetext{
${ }^{40}$ We conservatively estimate the annual wage for rural road workers as $75 \%$ of per capita income. This is probably too high, so our estimated range of employment benefits is probably conservative.

${ }^{41}$ First, we estimate the number of settlements abutting the network in each country. Using a Geographic Information System (GIS) and available spatial data, we develop relatively precise estimates of villages within $5 \mathrm{~km}$ of network roads in Mozambique, Mali and Burkina Faso. We divide total network distance in each country by the estimated number of settlements to obtain the estimated road interval separating settlements. The estimated intervals for the three countries are $2.70 \mathrm{~km}$ (Burkina Faso), $4.06 \mathrm{~km}$ (Mozambique) and $5.04 \mathrm{~km}$ (Mali). From these results, we set low- and high-range interval estimates for Africa at 2.5 and $6.0 \mathrm{~km}$. Then we multiply by network length in each country to obtain low and high numbers for settlements abutting network roads. Using the three-country spatial dataset, we also estimate the average populations per settlement in the network's 5-km buffer areas: 1,274 (Burkina Faso), 1,394 (Mozambique) and 700 (Mali). These averages are somewhat higher than for villages further than $5 \mathrm{~km}$ from a main road. For our extrapolation to other countries, we set the low- and high-range estimates at 500 and 1,500 people per settlement. We (very) conservatively bound our population estimates as follows: For each country, we obtain the lower-bound network-abutting population estimate by multiplying the lowerbound estimate of network-abutting settlements by the lower-bound estimate of population per village. We obtain the upper-bound population estimate by multiplying the upper-bound estimate of settlements by the upper-bound estimate of population per village.
} 
2.5 million person-years of employment and total labor income of $\$ 1.3$ billion.

Subsequent maintenance generates about 110,000 rural jobs, with an annual income flow of about $\$ 55$ million. Comparison of employment generated with the abutting population range indicates a large local labor deficit during the upgrade, with consequent overflow benefits for more distant settlements. Assuming that $40 \%$ of the local population is employable on road construction, ${ }^{42}$ annual maintenance demand can absorb between $4 \%$ and $26 \%$ of available labor in abutting settlements. In the full network, 18 countries have high-range absorption percentages of $10 \%$ or more.

For the whole trans-Africa network, we estimate that 8.4 million person-years of rural construction employment would be generated by initial upgrading, with about 365,000 rural jobs generated by annual maintenance. This would have a significant impact on employment and earnings in some of the poorest parts of rural Africa and, coupled with a clear prior understanding about the link between road siting and jobs, would probably be sufficient to motivate removal of barricades in most areas.

The second major source of income for local settlements would be growth in income-earning opportunities from large increases in network traffic. Abutting settlements would increase sales of goods and services to truckers and vehicle passengers, as well as having greatly-expanded export markets for local produce. To assess the potential scale of this effect, we have used GIS to define spatial corridors extending $10 \mathrm{~km}$ on either side of all network links. Overlaying these 20-km corridors on the most recent spatial population distribution map for rural Sub-Saharan Africa (SSA),

\footnotetext{
${ }^{42}$ Network countries have a mean population percentage of 53\% in the age range $15-64$.
} 
we find that approximately 67 million people, or 15\% of SSA's total rural population, reside within the corridors. ${ }^{43}$

For abutting settlements, we believe that increased income and employment from construction, maintenance, and sales of goods and services would easily compensate for any loss of barricade-extracted payments. Since the network's road monitoring teams would circulate daily, villagers would be constantly reminded of the link between income growth and barricade-free passage. As insurance, however, it is also worth thinking about direct payment programs that are explicitly tied to the absence of barricades. As an added incentive for local support, such programs could provide village development funds, micro-credit, or cash transfers conditional on barricade-free road conditions. ${ }^{44}$ They would probably work best if organized around regular payments in small increments, tied explicitly to monitored traffic flow.

We base our order-of-magnitude cost calculation for such a program on our estimate of abutting settlement numbers for the network, which we have explained in footnote 40. As we report in Appendix Table A6, the total number of settlements within $5 \mathrm{~km}$ of the continental network probably lies within the range $19,000-42,000$. If we assume that $20 \%$ of settlement areas require additional compensation, at $\$ 20,000$ per settlement annually, the total outlay is between $\$ 76$ million and $\$ 168$ million. To be conservative, we double the high-range estimate to $\$ 340$ million. We believe that such costs would plummet once the abutting settlements perceived the full benefits of the

\footnotetext{
${ }^{43}$ This estimate is based on GIS analysis of the GRUMP spatial population map (Balk et al., 2004). In this analysis, the rural population is estimated by masking urban areas, and then computing total population in remaining areas within $20-\mathrm{km}$ corridors around network links. This approach assumes that the rural population is uniformly distributed in each administrative area, after urban areas are masked. More detailed analysis of available datasets (e.g., for Mozambique) suggests non-uniform rural distributions, with higher population concentrations near network roads. This implies that our analysis probably underestimates Africa's rural population within the network's $20 \mathrm{~km}$ corridor.

${ }^{44}$ For a discussion of conditional cash transfer programs, see Das, Do and Ozler (2004).
} 
network and brought pressure to bear on recalcitrant barrier-erectors. However, we include $\$ 340$ million as a recurrent cost in our full accounting.

\subsection{Network Benefits and Costs: A Summary Accounting.}

We posit a 5-year period for network upgrading, followed by a 10-year period of network operation before a new upgrade would be needed. Our benchmark estimate for trade expansion is $\$ 19.7$ billion annually, or $\$ 197$ billion for the ten-year operational period. We assume that trade growth to full volume phases in continuously during the 5year initial upgrade period, which adds $\$ 49.2$ billion to total trade volume. The estimated cost of upgrading is $\$ 20.7$ billion, with an annual maintenance cost of $\$ 900$ million that would phase in during the first 5 years, and remain constant for the next 10 years. As we have previously noted, a significant percentage of these expenditures would generate jobs and income in high-poverty areas of rural Africa. Our estimate for the subcontinent is 8.4 million person-years of employment created by upgrading, and continuous employment of 365,000 people for maintenance. Conservative, order-of magnitude estimates for other cost categories include $\$ 500$ million annually for administration and network monitoring, and $\$ 350$ million annually for programs in abutting settlements. Table 16 summarizes the benefit and cost estimates. Among the imputed costs, we

roughly estimate that rural employment and income generation are directly tied to $35 \%$ of upgrading and maintenance expenditure and $100 \%$ of abutting settlement programs. This represents about $\$ 17$ billion in direct payments to high-poverty rural areas. It is worth repeating that our overall benefit estimate is extremely conservative, because it does not include either trade expansion among network cities within countries, greater trade with the rest of the world, or induced growth in rural and urban areas. 
To summarize, the balance sheet looks very good for network upgrading in SubSaharan Africa: total trade expansion between SSA countries over 15 years of $\$ 246$ billion, weighed against total costs of $\$ 47$ billion ( $\$ 5.9$ billion/year for the first five years and $\$ 1.8$ billion/year thereafter) for multilateral and bilateral funding agencies supporting a trans-African consortium. Even though the monetary value of trade expansion is not a direct measure of welfare gain, we can assume that the direct and indirect benefits of greater trade will far exceed the costs—especially if upgrading and maintenance programs ensure that a large proportion of investments (i.e., costs) yields significant local employment and expenditure multipliers. ${ }^{45}$

Table 16: Trans-African Road Network: 15-Year Benefit and Cost Estimates (\$US Billion)

\begin{tabular}{|l|r|r|}
\hline & $\begin{array}{l}\text { Upgrading } \\
\text { (5 Years) }\end{array}$ & $\begin{array}{l}\text { Operation } \\
\text { (10 Years) }\end{array}$ \\
\hline Trade Expansion & 49.25 & 197.00 \\
\hline Cost Components & & \\
\hline Upgrading & 20.70 & \\
\hline Maintenance & 4.50 & 9.00 \\
\hline Admin, Monitoring & 2.50 & 5.00 \\
\hline Settlement Programs & 1.75 & 3.50 \\
\hline & & \\
\hline Total Trade Expansion & 246.25 & \\
\hline Total Costs & 46.95 & \\
\hline
\end{tabular}

\section{Summary and Conclusions}

In this paper, we have estimated the benefits and costs of coordinated road network upgrading in Sub-Saharan Africa. Our simulated network uses minimum-distance routes over existing roads to connect 83 cities in mainland Sub-Saharan Africa: all 42 capital cities, as well as 41 other cities whose populations are 500,000 or greater. Using econometric estimates of gravity-model parameters for Sub-Saharan trade, we estimate

\footnotetext{
${ }^{45}$ See, for instance, Hertel and Winters (2005) for a recent discussion of the poverty reducing effects of increased trade.
} 
trade flows in the network between 3,403 city pairs. The model incorporates economic scale for origin and destination cities (proxied by their estimated total incomes), the network road distance between them, and road quality in each transshipment country. We compute trade volumes for the current road network, and for an upgraded network with road quality comparable to current levels in The Gambia and Zimbabwe. Our results suggest that coordinated upgrading of the network would expand overland trade by about $\$ 250$ billion over 15 years.

Using the World Bank's ROCKS database, we also estimate country-specific unit costs for upgrading and maintaining the 83-city road network. Our results indicate total expenditures of approximately $\$ 35$ billion for upgrading and maintenance over 15 years, of which about $\$ 12$ billion would directly generate jobs and income for about 8.4 million rural construction workers in the upgrade period, and 365,000 annual jobs for maintenance workers. We estimate additional 15-year costs of $\$ 12$ billion for administration, monitoring of road conditions, and programs that compensate abutting settlements for loss of revenue from barricades. Over 15 years, the implied annual implementation cost is $\$ 5.9$ billion for the first five years, and $\$ 1.8$ billion thereafter. This is well within the range of aid programs that are currently proposed for Sub-Saharan Africa.

We acknowledge that our network perspective incorporates a broad vision, and in closing we would like to address the question of feasibility. It is natural to ask whether an integrated trans-African road network is feasible, given Africa's many disappointments during the past several decades. We believe that a coordinated road upgrading program can succeed, for several reasons. First, the growing development gap 
between Sub-Saharan Africa and other regions has focused world attention and assistance on the region. Bilateral and multilateral development institutions have assigned Africa the highest priority, and donors appear willing to provide major resources for promising programs. Second, from a technical perspective, network upgrading can work because its goals are realistic. It seeks only to maintain basic quality standards in a limited network, rather than attempting improvement of all roads on the continent. Its operations and authority would be confined to the basic network of connector roads. It would avoid perverse financial incentives by leaving the greatest part of national road network improvement to budgetary support by national authorities. Third, all mainland SubSaharan countries should want to join the network, because their capitals and largest cities would be connected to it, and all would reap large gains from the expansion of trade. The potential gains should be sufficient for states to accept the desirability of streamlined border procedures and barricade-free roads. Fourth, we believe that large income increases from construction and service employment and expanded produce sales, coupled with direct compensation payments where needed, would provide sufficient incentives for road barricade removal. Fifth, and most important, we believe that coordinated road network upgrading is possible because Africa is ready for it. Governance is improving in many states, and a new, better-educated generation of leaders is ready to embrace the network's continental vision.

The final key to successful network upgrading would be willingness by donor countries to accept an unprecedented level of strategic coordination, as well as a 15-year commitment of approximately $\$ 47$ billion. The donors would collectively provide longterm financial, technical and institutional support for the network. In return, our results 
suggest that network upgrading would offer an important economic opportunity for the subcontinent. If Sub-Saharan countries are ready to collaborate on this scale, then the donor countries should be prepared to follow their lead. 


\section{References}

ADB, 2003, "Review of the Implementation Status of the Trans African Highways and the Missing Links," African Development Bank and UN Economic Commission for Africa, (consultants: SWECO International AB, Sweden; Nordic Consulting Group AB, Sweden, in association with BNETD, Ivory Coast and UNICONSULT, Kenya).

Amjadi, Azita and Alexander Yeats, 1995, "Have transport costs contributed to the relative decline of African exports? Some preliminary evidence," World Bank Working Papers on International Economics, Trade, and Capital Flows, No. 1559.

Anderson, James E., 1979, "A Theoretical Foundation for the Gravity Equation," American Economic Review 69, 106-116.

Balk, D., F. Pozzi, G. Yetman, U. Deichmann and A. Nelson, 2004, “The Distribution of People and the Dimension of Place: Methodologies to Improve the Global Estimation of Urban Extents," Center for International Earth Science Information Network, Columbia University, mimeo.

Bergstrand, Jeffrey H., 1985, “The Gravity Equation in International Trade: Some Microeconomic Foundations and Empirical Evidence," Review of Economics and Statistics 67, 471-481.

Bergstrand, Jeffrey H., 1989, “The Generalized Gravity Equation, Monopolistic Competition, and the Factor-Proportions Theory in International Trade," Review of Economics and Statistics 71, 143-153.

Bergstrand, Jeffrey H., 1990, “The Heckscher-Ohlin-Samuelson Model, the Linder Hypothesis, and the Determinants of Bilateral Intra-Industry Trade," Economic Journal 100, 1216-1229.

Carrillo, Carlos and Carmen Li, 2002, "Trade Blocks and the Gravity Model: Evidence from Latin American Countries," University of Essex, Discussion Paper.

Chauvin, Sophie. and Gillaume Gaulier, 2002, "Regional Trade Integration in Southern Africa," CEPII Research Center, Working Paper No. 2002-12.

Coulibaly, Souleymane and Lionel Fontagné, 2004, "South - South Trade: Geography Matters," CEPII Working Paper No. 2004-08, CEPII Research Center (forthcoming, Journal of African Economies - access online: October, 2005).

Das, Jishnu, Quy-Toan Do and Berk Özler, 2004, “Conditional Cash Transfers and the Equity-Efficiency Debate,” World Bank Development Research Group Working Paper, No. 3280, April. 
Deardorff, Alan V., 1998, "Determinants of Bilateral Trade: Does Gravity Work in a Classical World?" in Jeffrey A. Frankel (ed.), The Regionalization of the World Economy, Chicago: University of Chicago Press.

Feenstra, Robert C., James R. Markusen and Andrew K. Rose, 2001, "Using the gravity model equation to differentiate among alternative theories of trade," Canadian Journal of Economics 34, 430-447.

Frankel, Jeffrey A., 1997, Regional Trading Blocs in the World Trading System, Institute for International Economics: Washington D.C.

Heggie, I. and P. Vickers, 1998, "Commercial Management and Financing of Roads," World Bank Technical Paper No. 409, World Bank, Washington D.C.

Helpman, Elhanan and Paul Krugman, 1985, Market Structure and Foreign Trade, Cambridge, MA: MIT Press.

Hertel, Thomas W. and L. Alan Winters (2005), "Poverty Impacts of a WTO Agreement: Synthesis and Overview”, Policy Research Working Paper 3757, World Bank, Washington D.C.

Henderson J. V., Z. Shalizi and A. J. Venables, 2001, "Geography and development," Journal of Economic Geography 1, 81-105.

Kirkpatrick, C. and M. Watanabe, 2005, "Regional trade in sub-Saharan Africa: An analysis of East African trade cooperation, 1970-2001," The Manchester School 73(2), 141-164.

Limao, N. and A. J. Venables, 2000, "Infrastructure, geographical disadvantage, transport costs and trade," World Bank Economic Review, 15(3), 451-79.

Longo, Robert and Khalid Sekkat, 2004, "Economic Obstacles to Expanding IntraAfrican Trade," World Development, 32(8), 1309-1321.

Musila, Jacob, 2005, "The Intensity of Trade Creation and Trade Diversion in COMESA, ECCAS and ECOWAS: A Comparative Analysis," Journal of African Economies 14(1), 117-141.

Rossi-Hansberg, E., 2005, “A Spatial Theory of Trade,” American Economic Review, 95(5), 1464-1491.

Pandey, K., P. Buys, K. Chomitz and D. Wheeler, 2006, "Biodiversity Conservation Indicators: New Tools for Priority-Setting at the Global Environment Facility," World Bank Development Research Group Working Paper (forthcoming). 
Pöyhönen, Pentti, 1963, "A Tentative Model for the Volume of Trade between Countries," Weltwirtschaftliches Archiv 90, 93-99.

Rose, Andrew, 2000, “One Money, One Market: Estimating the Effect of Currency Unions on Trade," Economic Policy 15, 7-46.

Salopek, P., 2005, “Who Rules the Forest?” National Geographic, September, 74-95.

Simuyemba, S., 2000, “Linking Africa Through Regional Infrastructure,” African Development Bank, Economic Research Papers, No. 64.

Soloaga, Isidro and L. Alan Winters, 2001, "Regionalism in the Nineties: What Effect on Trade?" North American Journal of Economics and Finance 12, 1-29.

The Economist, 2002, "Trucking in Cameroon: The road to hell is unpaved," 19th December.

Tinbergen, Jan, 1962, “An Analysis of World Trade Flows,” in Jan Tinbergen (ed.), Shaping the World Economy, New York: The Twentieth Century Fund.

UNDP, 2002, "Re-Opening Mozambique: Lessons Learned from the Feeder Road Programme," UNDP: Maputo, Mozambique.

World Bank and Economic Commission for Africa, 2003, "Sub-Saharan Africa Transport Policy Program: Long-Term Development Plan 2004-2007," Africa Region, World Bank, April.

Yamarik, Steven and Sucharita Ghosh, 2005, "A Sensitivity Analysis of the Gravity Model," The International Trade Journal, 19(1), 83-126. 
Table A1

Trans-African Road Network Cities (*'s denote capital cities)

\begin{tabular}{|c|c|c|c|c|c|}
\hline Region & Country & City & Region & Country & City \\
\hline \multirow[t]{37}{*}{ West } & Benin & Cotonou* & South & South Africa & Soweto \\
\hline & Benin & Porto Novo & & South Africa & West Rand \\
\hline & Burkina Faso & Ouagadougou* & Central & Angola & Luanda* \\
\hline & Chad & N'Djamena* & & Burundi & Bujumbura* \\
\hline & Cote d'Ivoire & Abidjan* & & Cameroon & Douala \\
\hline & Cote d'Ivoire & Yamousoukro & & Cameroon & Yaounde* \\
\hline & Cote d'Ivoire & Bouake & & Central African Republic & Bangui* \\
\hline & Gambia, The & Banjul* & & Congo & Brazzaville* \\
\hline & Ghana & Accra* $^{\star}$ & & Congo & Pointe-Noire \\
\hline & Ghana & Kumasi & & D.R. of Congo & Kinshasa* \\
\hline & Guinea & Conakry* & & D.R. of Congo & Kananga \\
\hline & Guinea-Bissau & Bissau* & & D.R. of Congo & Kisangani \\
\hline & Liberia & Monrovia* & & D.R. of Congo & Kolwezi \\
\hline & Mali & Bamako* & & D.R. of Congo & Lubumbashi \\
\hline & Mauritania & Nouakchott* & & D.R. of Congo & Mbuji-Mayi \\
\hline & Niger & Niamey* & & Equatorial Guinea & Bata \\
\hline & Nigeria & Abeokuta & & Gabon & Libreville* \\
\hline & Nigeria & Abuja* & & Rwanda & Kigali* $^{\star}$ \\
\hline & Nigeria & Ado-Ekiti & & Zambia & Lusaka* \\
\hline & Nigeria & Enugu & East & Djibouti & Djibouti* \\
\hline & Nigeria & Ibadan & & Eritrea & Asmara* \\
\hline & Nigeria & Ilesha & & Ethiopia & Addis Ababa* \\
\hline & Nigeria & Ilorin & & Kenya & Mombasa \\
\hline & Nigeria & Iwo & & Kenya & Nairobi* \\
\hline & Nigeria & Kaduna & & Malawi & Blantyre-Limbe \\
\hline & Nigeria & Kano & & Malawi & Lilongwe* \\
\hline & Nigeria & Lagos & & Somalia & Mogadishu* \\
\hline & Nigeria & Maiduguri & & Sudan & Khartoum* \\
\hline & Nigeria & Mushin & & Tanzania & Dar es Salaam* \\
\hline & Nigeria & Ogbomosho & & Tanzania & Dodoma \\
\hline & Nigeria & Onitsha & Southern & Uganda & Kampala* \\
\hline & Nigeria & Oshogbo & & Botswana & Gaborone* $^{\star}$ \\
\hline & Nigeria & Port Harcourt & & Lesotho & Maseru* \\
\hline & Nigeria & Zaria & & Mozambique & Beira \\
\hline & Senegal & Dakar* & & Mozambique & Maputo* \\
\hline & Sierra Leone & Freetown* & & Namibia & Windhoek $^{*}$ \\
\hline & Togo & Lome $^{\star}$ & & Swaziland & Mbabane $^{\star}$ \\
\hline \multirow[t]{7}{*}{ South } & South Africa & Capetown & & Zimbabwe & Bulawayo \\
\hline & South Africa & Durban & & Zimbabwe & Harare* \\
\hline & South Africa & EastRand & & & \\
\hline & South Africa & Johannesburg & & & \\
\hline & South Africa & Pretoria* & & & \\
\hline & South Africa & Port Elizabeth & & & \\
\hline & South Africa & Sasolburg & & & \\
\hline
\end{tabular}


Table A2

Country Trade Impacts of Network Upgrading (\$US Million) ${ }^{\mathrm{a}}$

\begin{tabular}{|c|c|c|c|c|c|}
\hline Region & Country & Current & Upgraded & Change & $\begin{array}{c}\% \\
\text { Change }\end{array}$ \\
\hline \multirow[t]{15}{*}{ West } & Chad & 20.5 & 124.5 & 104.0 & 507.3 \\
\hline & Benin & 113.9 & 610.1 & 496.2 & 435.6 \\
\hline & Burkina Faso & 105.6 & 499.2 & 393.6 & 372.7 \\
\hline & Togo & 192.1 & 755.9 & 563.8 & 293.5 \\
\hline & Niger & 83.7 & 296.6 & 212.9 & 254.4 \\
\hline & Ghana & 403.4 & $1,304.1$ & 900.7 & 223.3 \\
\hline & Nigeria & $1,144.8$ & $3,134.5$ & $1,989.7$ & 173.8 \\
\hline & Mali & 149.9 & 371.5 & 221.6 & 147.8 \\
\hline & Cote d'Ivoire & 892.3 & $1,675.9$ & 783.6 & 87.8 \\
\hline & Guinea & 72.7 & 134.7 & 62.0 & 85.3 \\
\hline & Sierra Leone & 19.5 & 29.6 & 10.1 & 51.8 \\
\hline & Senegal & 307.1 & 427.7 & 120.6 & 39.3 \\
\hline & Guinea-Bissau & 15.9 & 22.1 & 6.2 & 39.0 \\
\hline & Gambia, The & 28.1 & 32.1 & 4.0 & 14.2 \\
\hline & Mauritania & 60.8 & 68.6 & 7.8 & 12.8 \\
\hline \multirow[t]{10}{*}{ Central } & Equatorial Guinea & 35.6 & 445.6 & 410.0 & $1,151.7$ \\
\hline & Gabon & 75.9 & 513.7 & 437.8 & 576.8 \\
\hline & Central African Republic & 10.7 & 58.3 & 47.6 & 444.9 \\
\hline & Congo, Democratic Republic of & 171.7 & 660.8 & 489.1 & 284.9 \\
\hline & Cameroon & 272.7 & 992.5 & 719.8 & 264.0 \\
\hline & Rwanda & 52.9 & 163.1 & 110.2 & 208.3 \\
\hline & Burundi & 22.5 & 56.1 & 33.6 & 149.3 \\
\hline & Angola & 209.3 & 470.6 & 261.3 & 124.8 \\
\hline & Congo, Republic of & 82.3 & 109.4 & 27.1 & 32.9 \\
\hline & Zambia & 502.5 & 632.8 & 130.3 & 25.9 \\
\hline \multirow[t]{8}{*}{ East } & Sudan & 55.1 & 621.0 & 565.9 & $1,027.0$ \\
\hline & Uganda & 253.3 & $2,131.1$ & $1,877.8$ & 741.3 \\
\hline & Ethiopia & 67.4 & 554.9 & 487.5 & 723.3 \\
\hline & Tanzania & 247.7 & $1,593.3$ & $1,345.6$ & 543.2 \\
\hline & Kenya & 510.6 & $3,060.4$ & $2,549.8$ & 499.4 \\
\hline & Eritrea & 3.7 & 6.3 & 2.6 & 70.3 \\
\hline & Malawi & 197.3 & 273.9 & 76.6 & 38.8 \\
\hline & Djibouti & 40.5 & 43.2 & 2.7 & 6.7 \\
\hline \multirow[t]{2}{*}{ Southern } & Mozambique & 448.5 & $1,202.3$ & 753.8 & 168.1 \\
\hline & Zimbabwe & 673.2 & 772.4 & 99.2 & 14.7 \\
\hline South & South Africa & $2,499.9$ & $5,851.6$ & $3,351.7$ & 134.1 \\
\hline
\end{tabular}

* Current trade values are the averages of total exports and total imports for 2000-2003. 
Table A3

City Trade Impacts of Network Upgrading

(\$US Million)

\begin{tabular}{|c|c|c|c|c|c|c|}
\hline Region & Country & City & Current & Upgraded & Change & $\begin{array}{c}\% \\
\text { Change }\end{array}$ \\
\hline \multirow[t]{36}{*}{ West } & Benin & Cotonou & 97 & 528 & 431 & 444 \\
\hline & Benin & Porto Novo & 17 & 82 & 65 & 382 \\
\hline & Burkina Faso & Ouagadougou & 106 & 499 & 393 & 371 \\
\hline & Chad & N'Djamena & 21 & 125 & 104 & 495 \\
\hline & Cote d'Ivoire & Abidjan & 813 & 1,507 & 694 & 85 \\
\hline & Cote d'Ivoire & Bouake & 49 & 107 & 58 & 118 \\
\hline & Cote d'Ivoire & Yamoussoukro & 30 & 63 & 33 & 110 \\
\hline & Gambia, The & Banjul & 28 & 32 & 4 & 14 \\
\hline & Ghana & Accra & 352 & 1,155 & 803 & 228 \\
\hline & Ghana & Kumasi & 51 & 149 & 98 & 192 \\
\hline & Guinea & Conakry & 73 & 135 & 62 & 85 \\
\hline & Guinea-Bissau & Bissau & 16 & 22 & 6 & 38 \\
\hline & Mali & Bamako & 150 & 372 & 222 & 148 \\
\hline & Mauritania & Nouakchott & 61 & 69 & 8 & 13 \\
\hline & Niger & Niamey & 84 & 297 & 213 & 254 \\
\hline & Nigeria & Abuja & 3 & 9 & 6 & 200 \\
\hline & Nigeria & Abeokuta & 8 & 23 & 15 & 188 \\
\hline & Nigeria & Ado-Ekiti & 4 & 14 & 10 & 250 \\
\hline & Nigeria & Enugu & 5 & 18 & 13 & 260 \\
\hline & Nigeria & Ibadan & 35 & 99 & 64 & 183 \\
\hline & Nigeria & Ilesha & 7 & 21 & 14 & 200 \\
\hline & Nigeria & Ilorin & 8 & 22 & 14 & 175 \\
\hline & Nigeria & Iwo & 6 & 16 & 10 & 167 \\
\hline & Nigeria & Kaduna & 4 & 12 & 8 & 200 \\
\hline & Nigeria & Kano & 7 & 35 & 28 & 400 \\
\hline & Nigeria & Lagos & 1,001 & 2,675 & 1,674 & 167 \\
\hline & Nigeria & Maiduguri & 2 & 19 & 17 & 850 \\
\hline & Nigeria & Mushin & 6 & 19 & 13 & 217 \\
\hline & Nigeria & Ogbomosho & 24 & 68 & 44 & 183 \\
\hline & Nigeria & Onitsha & 6 & 21 & 15 & 250 \\
\hline & Nigeria & Oshogbo & 8 & 23 & 15 & 188 \\
\hline & Nigeria & PortHarcourt & 7 & 24 & 17 & 243 \\
\hline & Nigeria & Zaria & 3 & 15 & 12 & 400 \\
\hline & Senegal & Dakar & 307 & 428 & 121 & 39 \\
\hline & Sierra Leone & Freetown & 20 & 30 & 10 & 50 \\
\hline & Togo & Lome & 192 & 756 & 564 & 294 \\
\hline
\end{tabular}




\begin{tabular}{|c|c|c|c|c|c|c|}
\hline Region & Country & City & Current & Upgraded & Change & $\begin{array}{c}\% \\
\text { Change }\end{array}$ \\
\hline \multirow[t]{17}{*}{ Central } & Angola & Luanda & 209 & 471 & 262 & 125 \\
\hline & Burundi & Bujumbura & 22 & 56 & 34 & 155 \\
\hline & Cameroon & Douala & 163 & 569 & 406 & 249 \\
\hline & Cameroon & Yaounde & 110 & 423 & 313 & 285 \\
\hline & Central African Republic & Bangui & 11 & 58 & 47 & 427 \\
\hline & Congo & Brazzaville & 58 & 77 & 19 & 33 \\
\hline & Congo & Pointe-Noire & 24 & 33 & 9 & 38 \\
\hline & D.R. of Congo & Kinshasa & 99 & 417 & 318 & 321 \\
\hline & D.R. of Congo & Kananga & 5 & 19 & 14 & 280 \\
\hline & D.R. of Congo & Kisangani & 7 & 21 & 14 & 200 \\
\hline & D.R. of Congo & Kolwezi & 15 & 52 & 37 & 247 \\
\hline & D.R. of Congo & Lubumbashi & 33 & 106 & 73 & 221 \\
\hline & D.R. of Congo & Mbuji-Mayi & 12 & 45 & 33 & 275 \\
\hline & Equatorial Guinea & Bata & 36 & 446 & 410 & 1,139 \\
\hline & Gabon & Libreville & 76 & 514 & 438 & 576 \\
\hline & Rwanda & Kigali & 53 & 163 & 110 & 208 \\
\hline & Zambia & Lusaka & 502 & 633 & 131 & 26 \\
\hline \multirow[t]{11}{*}{ East } & Djibouti & Djibouti & 41 & 43 & 2 & 5 \\
\hline & Eritrea & Asmara & 4 & 6 & 2 & 50 \\
\hline & Ethiopia & Addis Ababa & 67 & 555 & 488 & 728 \\
\hline & Kenya & Mombasa & 73 & 566 & 493 & 675 \\
\hline & Kenya & Nairobi & 437 & 2,495 & 2,058 & 471 \\
\hline & Malawi & Blantyre-Limbe & 94 & 132 & 38 & 40 \\
\hline & Malawi & Lilongwe & 103 & 142 & 39 & 38 \\
\hline & Sudan & Khartoum & 55 & 621 & 566 & 1,029 \\
\hline & Tanzania & Dodoma & 5 & 32 & 27 & 540 \\
\hline & Tanzania & Dar es Salaam & 243 & 1,561 & 1,318 & 542 \\
\hline & Uganda & Kampala & 253 & 2,131 & 1,878 & 742 \\
\hline \multirow[t]{4}{*}{ Southern } & Mozambique & Beira & 24 & 44 & 20 & 83 \\
\hline & Mozambique & Maputo & 425 & 1,159 & 734 & 173 \\
\hline & Zimbabwe & Bulawayo & 228 & 248 & 20 & 9 \\
\hline & Zimbabwe & Harare & 445 & 524 & 79 & 18 \\
\hline \multirow[t]{9}{*}{ South } & South Africa & Capetown & 389 & 1,033 & 644 & 166 \\
\hline & South Africa & Durban & 175 & 443 & 268 & 153 \\
\hline & South Africa & East Rand & 438 & 987 & 549 & 125 \\
\hline & South Africa & Johannesburg & 655 & 1,459 & 804 & 123 \\
\hline & South Africa & Pretoria & 313 & 694 & 381 & 122 \\
\hline & South Africa & Port Elizabeth & 81 & 214 & 133 & 164 \\
\hline & South Africa & Sasolburg & 162 & 371 & 209 & 129 \\
\hline & South Africa & Soweto & 87 & 197 & 110 & 126 \\
\hline & South Africa & West Rand & 201 & 453 & 252 & 125 \\
\hline
\end{tabular}


Table A4

Network Upgrade Costs by Country

\begin{tabular}{|c|c|c|c|c|c|c|c|c|}
\hline \multirow[b]{2}{*}{ Region } & \multirow[b]{2}{*}{ Country } & \multicolumn{3}{|c|}{ Total Upgrade Cost (\$US Million) } & \multicolumn{3}{|c|}{ Upgrade Cost Per Km （\$US ‘000) } & \multirow{2}{*}{$\begin{array}{c}\text { Network } \\
\text { Length } \\
(\mathrm{Km})\end{array}$} \\
\hline & & Baseline & $\begin{array}{c}\text { Low } \\
(-1 \mathrm{SE})\end{array}$ & $\begin{array}{c}\text { High } \\
(+1 \mathrm{SE})\end{array}$ & Baseline & $\begin{array}{c}\text { Low } \\
\text { (-1 SE) }\end{array}$ & $\begin{array}{c}\text { High } \\
(+1 \mathrm{SE})\end{array}$ & \\
\hline West & Benin & 90 & 80 & 101 & 97 & 86 & 109 & 931 \\
\hline West & Burkina Faso & 215 & 179 & 258 & 135 & 113 & 162 & 1,590 \\
\hline West & Chad & 372 & 310 & 447 & 180 & 150 & 216 & 2,071 \\
\hline West & Cote d'Ivoire & 327 & 261 & 409 & 194 & 155 & 243 & 1,686 \\
\hline West & Gambia, The & 14 & 10 & 20 & 135 & 94 & 193 & 105 \\
\hline West & Ghana & 205 & 194 & 217 & 97 & 91 & 102 & 2,120 \\
\hline West & Guinea & 669 & 460 & 972 & 245 & 168 & 356 & 2,733 \\
\hline West & Guinea-Bissau & 112 & 75 & 168 & 250 & 168 & 373 & 450 \\
\hline West & Liberia & 102 & 76 & 138 & 209 & 155 & 283 & 489 \\
\hline West & Mali & 240 & 212 & 272 & 116 & 102 & 131 & 2,077 \\
\hline West & Mauritania & 65 & 42 & 99 & 309 & 202 & 474 & 209 \\
\hline West & Niger & 126 & 109 & 146 & 126 & 109 & 146 & 999 \\
\hline West & Nigeria & 554 & 474 & 646 & 70 & 60 & 82 & 7,890 \\
\hline West & Senegal & 240 & 186 & 309 & 122 & 95 & 157 & 1,964 \\
\hline West & Sierra Leone & 96 & 73 & 125 & 157 & 120 & 205 & 609 \\
\hline West & Togo & 50 & 45 & 55 & 71 & 64 & 78 & 703 \\
\hline Central & Angola & 1,704 & 1,115 & 2,604 & 586 & 384 & 896 & 2,906 \\
\hline Central & Burundi & 30 & 23 & 39 & 109 & 83 & 144 & 272 \\
\hline Central & Cameroon & 1,497 & 1,079 & 2,079 & 441 & 318 & 612 & 3,398 \\
\hline Central & $\begin{array}{l}\text { Central African } \\
\text { Republic }\end{array}$ & 1,235 & 898 & 1,698 & 520 & 378 & 715 & 2,375 \\
\hline Central & $\begin{array}{l}\text { Congo, Democratic } \\
\text { Republic of }\end{array}$ & 3,498 & 2,856 & 4,283 & 343 & 280 & 421 & 10,185 \\
\hline Central & Congo & 343 & 255 & 461 & 396 & 294 & 532 & 867 \\
\hline Central & Equatorial Guinea & 60 & 41 & 88 & 550 & 376 & 804 & 109 \\
\hline Central & Gabon & 1,709 & 781 & 3,740 & 1,588 & 726 & 3,477 & 1,076 \\
\hline Central & Rwanda & 37 & 33 & 42 & 178 & 158 & 200 & 208 \\
\hline Central & Zambia & 481 & 428 & 541 & 136 & 121 & 153 & 3,534 \\
\hline East & Djibouti & 92 & 69 & 121 & 388 & 294 & 512 & 236 \\
\hline East & Eritrea & 33 & 29 & 37 & 139 & 124 & 156 & 236 \\
\hline East & Ethiopia & 999 & 858 & 1,163 & 236 & 203 & 274 & 4,239 \\
\hline East & Kenya & 367 & 319 & 422 & 147 & 127 & 169 & 2,504 \\
\hline East & Malawi & 161 & 139 & 186 & 130 & 113 & 151 & 1,236 \\
\hline East & Somalia & 293 & 232 & 371 & 113 & 90 & 143 & 2,590 \\
\hline East & Sudan & 406 & 340 & 484 & 124 & 104 & 148 & 3,282 \\
\hline East & Tanzania & 644 & 537 & 773 & 158 & 132 & 189 & 4,080 \\
\hline East & Uganda & 415 & 381 & 451 & 243 & 223 & 264 & 1,708 \\
\hline Southern & Botswana & 255 & 180 & 359 & 99 & 70 & 139 & 2,580 \\
\hline Southern & Lesotho & 1 & 0 & 1 & 204 & 180 & 231 & 2 \\
\hline Southern & Mozambique & 742 & 660 & 834 & 190 & 169 & 213 & 3,910 \\
\hline Southern & Namibia & 1,201 & 846 & 1,706 & 472 & 332 & 670 & 2,547 \\
\hline Southern & Swaziland & 159 & 97 & 259 & 622 & 381 & 1,014 & 255 \\
\hline Southern & Zimbabwe & 189 & 149 & 239 & 82 & 65 & 104 & 2,288 \\
\hline \multirow[t]{2}{*}{ South } & South Africa & 693 & 471 & 1,017 & 80 & 55 & 118 & 8,655 \\
\hline & Total & 20,715 & 15,601 & 28,380 & & & & \\
\hline
\end{tabular}


Table A5

Network Maintenance Costs by Country

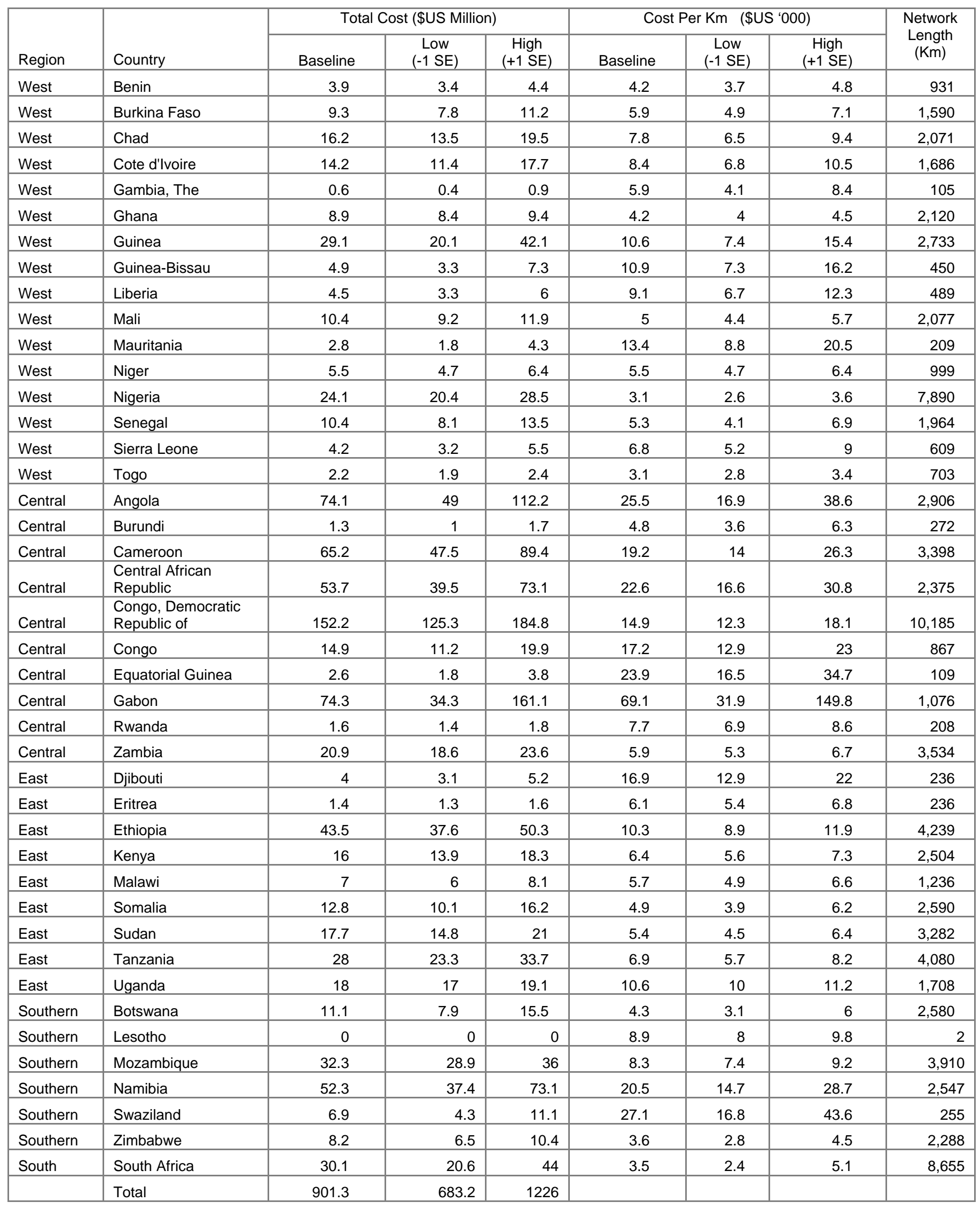


Table A6: Network Villages, Population and Construction Employment

\begin{tabular}{|c|c|c|c|c|c|c|c|c|c|}
\hline Region & Country & $\begin{array}{l}\text { Network } \\
\text { Length } \\
(\mathrm{km})\end{array}$ & $\begin{array}{l}\text { Villages } \\
\text { (Low) }\end{array}$ & $\begin{array}{l}\text { Villages } \\
\text { (High) }\end{array}$ & $\begin{array}{l}\text { Village } \\
\text { Pop. } \\
\text { (Low) }\end{array}$ & $\begin{array}{l}\text { Village } \\
\text { Pop. } \\
\text { (High) }\end{array}$ & $\begin{array}{l}\text { Upgrade } \\
\text { Person- } \\
\text { Years }\end{array}$ & $\begin{array}{l}\text { Maint. } \\
\text { Person- } \\
\text { Years }\end{array}$ & $\begin{array}{l}\text { Ann. } \\
\text { Wage } \\
\text { (\$US) }\end{array}$ \\
\hline \multirow[t]{16}{*}{ West } & Benin & 932 & 155 & 373 & 77,694 & 559,396 & 41,964 & 1,826 & 749 \\
\hline & Burkina Faso & 1,590 & 589 & 589 & 750,197 & 750,197 & 95,712 & 4,165 & 785 \\
\hline & Chad & 2,076 & 346 & 831 & 173,026 & $1,245,788$ & 193,115 & 8,403 & 675 \\
\hline & Cote d'Ivoire & 1,767 & 295 & 707 & 147,273 & $1,060,363$ & 99,050 & 4,310 & 1,156 \\
\hline & Gambia, The & 125 & 21 & 50 & 10,421 & 75,034 & 3,742 & 163 & 1,331 \\
\hline & Ghana & 2,203 & 367 & 881 & 183,624 & $1,322,093$ & 48,012 & 2,089 & 1,493 \\
\hline & Guinea & 2,968 & 495 & 1,187 & 247,324 & $1,780,731$ & 157,089 & 6,836 & 1,490 \\
\hline & Guinea-Bissau & 450 & 75 & 180 & 37,459 & 269,704 & 66,264 & 2,883 & 594 \\
\hline & Liberia & 624 & 104 & 249 & 51,962 & 374,123 & 67,655 & 2,944 & 529 \\
\hline & Mali & 3,303 & 656 & 656 & 459,364 & 459,364 & 122,639 & 5,337 & 685 \\
\hline & Mauritania & 1,671 & 279 & 669 & 139,290 & $1,002,888$ & 17,561 & 764 & 1,286 \\
\hline & Niger & 2,562 & 427 & 1,025 & 213,519 & $1,537,335$ & 76,032 & 3,308 & 580 \\
\hline & Nigeria & 8,484 & 1,414 & 3,393 & 706,978 & $5,090,238$ & 297,046 & 12,926 & 652 \\
\hline & Senegal & 2,105 & 351 & 842 & 175,411 & $1,262,962$ & 73,415 & 3,195 & 1,142 \\
\hline & Sierra Leone & 684 & 114 & 274 & 57,007 & 410,453 & 94,707 & 4,121 & 353 \\
\hline & Togo & 703 & 117 & 281 & 58,568 & 421,693 & 14,848 & 646 & 1,173 \\
\hline \multirow[t]{10}{*}{ Central } & Angola & 4,270 & 712 & 1,708 & 355,875 & $2,562,297$ & 418,732 & 18,221 & 1,424 \\
\hline & Burundi & 272 & 45 & 109 & 22,654 & 163,112 & 22,952 & 999 & 453 \\
\hline & Cameroon & 3,896 & 649 & 1,558 & 324,633 & $2,337,355$ & 357,020 & 15,535 & 1,468 \\
\hline & Central African Republic & 2,544 & 424 & 1,018 & 212,004 & $1,526,426$ & 500,527 & 21,780 & 864 \\
\hline & Congo & 903 & 151 & 361 & 75,285 & 542,051 & 164,425 & 7,155 & 730 \\
\hline & Democratic Republic of Congo & 12,184 & 2,031 & 4,874 & $1,015,329$ & $7,310,370$ & $2,461,554$ & 107,112 & 497 \\
\hline & Equatorial Guinea & 109 & 18 & 44 & 9,102 & 65,537 & 28,037 & 1,220 & 750 \\
\hline & Gabon & 1,085 & 181 & 434 & 90,406 & 650,923 & 130,815 & 5,692 & 4,572 \\
\hline & Rwanda & 344 & 57 & 137 & 28,638 & 206,193 & 14,955 & 651 & 866 \\
\hline & Zambia & 3,667 & 611 & 1,467 & 305,557 & $2,200,013$ & 281,325 & 12,242 & 598 \\
\hline \multirow[t]{9}{*}{ East } & Djibouti & 257 & 43 & 103 & 21,392 & 154,024 & 22,112 & 962 & 1,449 \\
\hline & Eritrea & 620 & 103 & 248 & 51,683 & 372,118 & 19,165 & 834 & 600 \\
\hline & Ethiopia & 4,435 & 739 & 1,774 & 369,582 & $2,660,992$ & 658,438 & 28,651 & 531 \\
\hline & Kenya & 3,383 & 564 & 1,353 & 281,883 & $2,029,557$ & 172,455 & 7,504 & 744 \\
\hline & Malawi & 1,236 & 206 & 494 & 103,015 & 741,706 & 134,884 & 5,869 & 417 \\
\hline & Somalia & 2,868 & 478 & 1,147 & 239,024 & $1,720,971$ & 160,973 & 7,005 & 638 \\
\hline & Sudan & 4,475 & 746 & 1,790 & 372,887 & $2,684,788$ & 109,711 & 4,774 & 1,294 \\
\hline & Tanzania & 5,145 & 858 & 2,058 & 428,782 & $3,087,229$ & 562,231 & 24,465 & 401 \\
\hline & Uganda & 1,727 & 288 & 691 & 143,899 & $1,036,072$ & 148,252 & 6,451 & 979 \\
\hline \multirow[t]{6}{*}{ Southern } & Botswana & 2,874 & 479 & 1,150 & 239,506 & $1,724,444$ & 15,831 & 689 & 5,626 \\
\hline & Lesotho & 4 & 1 & 2 & 358 & 2,574 & 95 & 4 & 1,700 \\
\hline & Mozambique & 4,148 & 1,023 & 1,023 & $1,425,869$ & $1,425,869$ & 347,803 & 15,134 & 746 \\
\hline & Namibia & 3,312 & 552 & 1,325 & 275,991 & $1,987,132$ & 91,465 & 3,980 & 4,596 \\
\hline & Swaziland & 255 & 43 & 102 & 21,252 & 153,014 & 17,208 & 749 & 3,226 \\
\hline & Zimbabwe & 2,756 & 459 & 1,102 & 229,684 & $1,653,728$ & 38,144 & 1,660 & 1,731 \\
\hline \multirow[t]{2}{*}{ South } & South Africa & 9,802 & 1,634 & 3,921 & 816,816 & $5,881,073$ & 33,685 & 1,466 & 7,195 \\
\hline & Total & 108,818 & 18,900 & 42,180 & $10,950,223$ & $62,501,930$ & $8,381,645$ & 364,720 & \\
\hline
\end{tabular}


Table A7: Trade Agreements in Sub-Saharan Africa

\begin{tabular}{|c|c|c|c|c|c|c|}
\hline Country & WAEMU & CEMAC & EAC & ECOWAS & $\underline{S A D C}$ & COMESA \\
\hline Benin & $\mathrm{x}$ & & & $\mathrm{x}$ & & \\
\hline Burkina Faso & $x$ & & & $x$ & & \\
\hline Cote d'Ivoire & $\mathrm{x}$ & & & $\mathrm{x}$ & & \\
\hline Guinea-Bissau & $x$ & & & $x$ & & \\
\hline Mali & $\mathrm{x}$ & & & $\mathrm{x}$ & & \\
\hline Niger & $x$ & & & $x$ & & \\
\hline Senegal & $x$ & & & $x$ & & \\
\hline Togo & $x$ & & & $x$ & & \\
\hline Cameroon & & $\mathrm{x}$ & & & & \\
\hline Central African Republic & & $x$ & & & & \\
\hline Chad & & $x$ & & & & \\
\hline Congo & & $x$ & & & & \\
\hline Equatorial Guinea & & $x$ & & & & \\
\hline Gabon & & $x$ & & & & \\
\hline Kenya & & & $x$ & & & $x$ \\
\hline Tanzania & & & $\mathrm{x}$ & & $\mathrm{x}$ & \\
\hline Uganda & & & $x$ & & & $x$ \\
\hline Gambia, The & & & & $x$ & & \\
\hline Ghana & & & & $x$ & & \\
\hline Guinea & & & & $x$ & & \\
\hline Liberia & & & & $\mathrm{x}$ & & \\
\hline Nigeria & & & & $x$ & & \\
\hline Sierra Leone & & & & $x$ & & \\
\hline Angola & & & & & $x$ & $x$ \\
\hline Botswana & & & & & $\mathrm{x}$ & \\
\hline Dem.Rep. of Congo & & & & & $x$ & $x$ \\
\hline Lesotho & & & & & $x$ & \\
\hline Malawi & & & & & $\mathrm{x}$ & $\mathrm{x}$ \\
\hline Mozambique & & & & & $\mathrm{x}$ & \\
\hline Namibia & & & & & $\mathrm{x}$ & \\
\hline South Africa & & & & & $x$ & \\
\hline Swaziland & & & & & $\mathrm{x}$ & $\mathrm{x}$ \\
\hline Zambia & & & & & $\mathrm{x}$ & $\mathrm{x}$ \\
\hline Zimbabwe & & & & & $x$ & $x$ \\
\hline Burundi & & & & & & $x$ \\
\hline Djibouti & & & & & & $\mathrm{x}$ \\
\hline Eritrea & & & & & & $\mathrm{x}$ \\
\hline Ethiopia & & & & & & $x$ \\
\hline Rwanda & & & & & & $x$ \\
\hline Sudan & & & & & & $x$ \\
\hline Mauritania & & & & & & \\
\hline Somalia & & & & & & \\
\hline
\end{tabular}

